\title{
Magneto-Responsive Hydrogels: Preparation, Characterization, Biotechnological and Environmental Applications
}

\author{
Emilli C. G. Frachini ${ }^{\circledR a}$ and Denise F. S. Petri ${ }^{\circledR} * a$ \\ ${ }^{a}$ Departamento de Química Fundamental, Instituto de Química, Universidade de São Paulo, \\ Av. Prof. Lineu Prestes 748, 05508-000 São Paulo-SP, Brazil
}

\begin{abstract}
Hydrogels are hydrophilic three-dimensional networks able to hold large amount of water and hydrophilic molecules. Magneto-responsive hydrogels comprise of magnetic nanoparticles dispersed in polymeric networks that can be manipulated under external magnetic field. This review aims at $(i)$ giving a brief overview on the evolution of hydrogels until the design and development of magnetic hydrogels; (ii) describing the types of hydrogels and the basic concepts about superparamagnetic iron oxide nanoparticles, as well as the preparation and characterization of magneto-responsive hydrogels; (iii) displaying the relevant applications of magneto-responsive hydrogels for drug delivery, regenerative medicine of tissues, cancer therapy and environmental issues and $(i v)$ highlighting the challenges and future trends of magneto-responsive hydrogels for 3D and 4D printing.
\end{abstract}

Keywords: magnetic hydrogel, drug delivery, tissue engineering, environmental remediation, $3 \mathrm{D}$ and $4 \mathrm{D}$ printing

\section{Introduction}

The paper is organized as follows. The "Introduction" section shows $(i)$ the chronological evolution from gels to magnetic hydrogels; (ii) the classification of polymer hydrogels regarding their chemical and physical aspects and (iii) the basic concepts about superparamagnetic particles. "Methods for the Preparation of Magnetic Hydrogels" section presents the different methods for the preparation and characterization of magnetic hydrogels. "Biomedical Applications of Magnetic Hydrogel" section describes the application of magnetic hydrogels for drug delivery, tissue engineering and cancer therapy. "Environmental Applications" section shows the application of magnetic hydrogels for remediation of contaminated water. Finally, "Future Trends and Challenges" section discusses about the challenges and future trends regarding the $3 D$ and $4 D$ printing of magnetic hydrogels.

\subsection{A brief overview}

At the beginning of this review, it seems relevant to revisit the origins of the "gel" concept. In 1861, Thomas Graham ${ }^{1}$ defined "the colloidal condition" of matter, which

*e-mail: dfsp@iq.usp.br regarded real solutions of high molar mass substances such as gelatin, albumin, dextran, which could form superior gelatinous hydrates. Approximately 50 years later, Freundlich, Ostwald and Weimarn proposed that colloid could be any substance in a dispersed "colloidal" state, regardless of the molar mass; thus, suspensions of fine inorganic or metal particles or emulsions could also be considered colloids. ${ }^{2}$ Although the definition of colloids was established, gels were easier to recognize than to define. ${ }^{3}$ Three points characterized gels: (i) they are coherent colloid disperse systems of at least two components; (ii) they display mechanical properties characteristic of the solid state and (iii) both the dispersed component and the continuous medium extent themselves continuously throughout the whole system. Moreover, there were two fundamental conditions to create gel from solutions: (i) the solid substance should separate from the solution in a finely dispersed "colloidal" state and (ii) the separated solid particles should not deposit at the bottom nor remain as individual moving particles, but they should form a coherent framework throughout the volume. ${ }^{4}$ It is amazing that despite the simple instruments or low technology available at that time, the fundamental aspects that defined gels are still valid nowadays. One century ago, gels that could be liquefied and solidified by changing the temperature, such as gelatin in water or agar-agar in water, 
were classified as heat-reversible and non-heat-reversible gels; today we refer to gels with similar behavior as thermoresponsive gels.

Most gels investigated in the remote past were in fact hydrogels, because they were proteins (albumin, gelatin) or polysaccharides (starch, agar-agar) that formed networks in water. In 1960, the term hydrogels appeared in connection with applications where the gels would be in contact with living tissues and the requirements to make them suitable (swelling, porosity, mechanical properties), particularly the crosslinking of 2-hydroxyethyl methacrylate to create hydrogels contact lens. ${ }^{5}$ Since then, hydrogels have been widely explored for drug delivery systems, biomedical devices and tissue engineering. Natural macromolecules, polysaccharides and proteins proved to be good candidates to compose the hydrogels because they can be easily crosslinked, they are biocompatible and biodegradable. Hydrophilic synthetic polymers, such as poly(ethylene glycol) or poly(vinyl alcohol), and biodegradable poly(lactic acid) are also widely used as hydrogels due to their biocompatibility.

Reversible contraction and expansion of poly(acrylic acid) hydrogels by changing of medium $\mathrm{pH}$ were reported by Kuhn ${ }^{6}$ in 1949, who glimpsed the similarity to muscle contraction. He proposed that, in water or alkaline medium, the polymer chains were negatively charged, causing electrostatic repulsion among them and gel stretching; under acid medium, carboxylate groups were protonated, allowing the polymer chains to coil and contract. This work by Kuhn practically launched the concept of smart gels. Nowadays, smart or stimuli-responsive hydrogels are defined as those that reversibly undergo dimensional changes in response to environmental stimuli. ${ }^{7}$ The physical stimuli include changes in temperature or pressure, intermittent exposition to electric field, magnetic field or light. The chemical stimuli refer to changes in the medium $\mathrm{pH}$ and/or ionic strength or to the activity of enzymes or to specific molecular recognition. ${ }^{8}$

Particularly regarding the magneto-responsive hydrogels, the first report dates back 30 years ago with the pioneer work by Kost et al. ${ }^{9}$ in 1987 , who reported about the magnetically stimulated in vivo release of insulin from magnetic poly(ethylene-co-vinyl acetate) hydrogels under oscillating external magnetic field (EMF). Since then, innumerous magnetic hydrogels have been developed for drug delivery, ${ }^{10}$ tissue engineering, ${ }^{11}$ diagnostics ${ }^{12}$ and for environmental issues. ${ }^{13}$ The latest trends related to hydrogels refer to injectable hydrogels and 3D (bio) printing, which enable precision in the regenerative process due to the precise construction of biomimetic matrices and positioning of cells and biomolecules embedded in the hydrogels. ${ }^{14}$ The $4 \mathrm{D}$ printing concept relies on the condition that the $3 \mathrm{D}$ printed object is stimuli responsive, ${ }^{15,16}$ making magnetic hydrogels potential candidates for 4D printing because they offer the possibility to undergo reversible shape change under EMF.

\subsection{Classification of polymer hydrogels}

Polymer hydrogels can be made of natural or synthetic polymers, charged or uncharged. Homopolymers (one type of monomeric unit), copolymers (two or more different monomers) and blends of polymers can be used to produce hydrogels. The interchain interactions can be of physical or chemical nature. ${ }^{17}$ In physical gels, the polymer chains are kept together by hydrogen bonds, hydrophobic or van der Waals forces and chemical hydrogels contain covalent bonds between polymer chains. ${ }^{18}$ Changes in temperature, pressure or mechanical stress might affect the stability of physical gels. Contrarily, chemical hydrogels present high stability upon changes in the physical and chemical conditions because the polymer chains are chemically crosslinked. ${ }^{19}$ Based on the pore size, hydrogels can be classified as nanogels (1 to $100 \mathrm{~nm}),{ }^{20}$ microgels $(100 \mathrm{~nm}$ to $5 \mu \mathrm{m})^{21}$ and macrogels $(>1 \mathrm{~mm}$ ). All these features, schematically represented in Figure 1, drive the final properties and applications of hydrogels.

Interpenetrating polymer network (IPN) is a sub-category of polymer hydrogels and can be classified as full-IPN or semi-IPN. ${ }^{22}$ For example, considering polymers A and B, in the full IPN the chains from polymer A are crosslinked with each other and chains from polymer B are also crosslinked with each other, but crosslinking among chains from polymers A and B is not present. In the semi-IPN the chains from polymer A are crosslinked with each other and chains from polymer B are only physically entrapped therein. Figure 2 represents chemical and physical hydrogels, semi- and full-IPN.

\subsection{Superparamagnetic iron oxide nanoparticles}

Superparamagnetic iron oxide nanoparticles (SPIONs) are magnetic nanoparticles (MNP), such as magnetite $\left(\mathrm{Fe}_{3} \mathrm{O}_{4}\right)$ and maghemite $\left(\gamma-\mathrm{Fe}_{2} \mathrm{O}_{3}\right)$, with superparamagnetic properties. ${ }^{23}$ Due to their small size $(<50 \mathrm{~nm})$ SPIONs are considered as single magnetic domain and its magnetization is envisaged as the sum of all the individual magnetic moments of each atom that compose the nanoparticle. SPIONs present magnetic anisotropy, which means that the magnetic moment has two stable antiparallel orientations separated by an energy barrier. The magnetization can flip and reverse the direction of magnetic moment as result of 


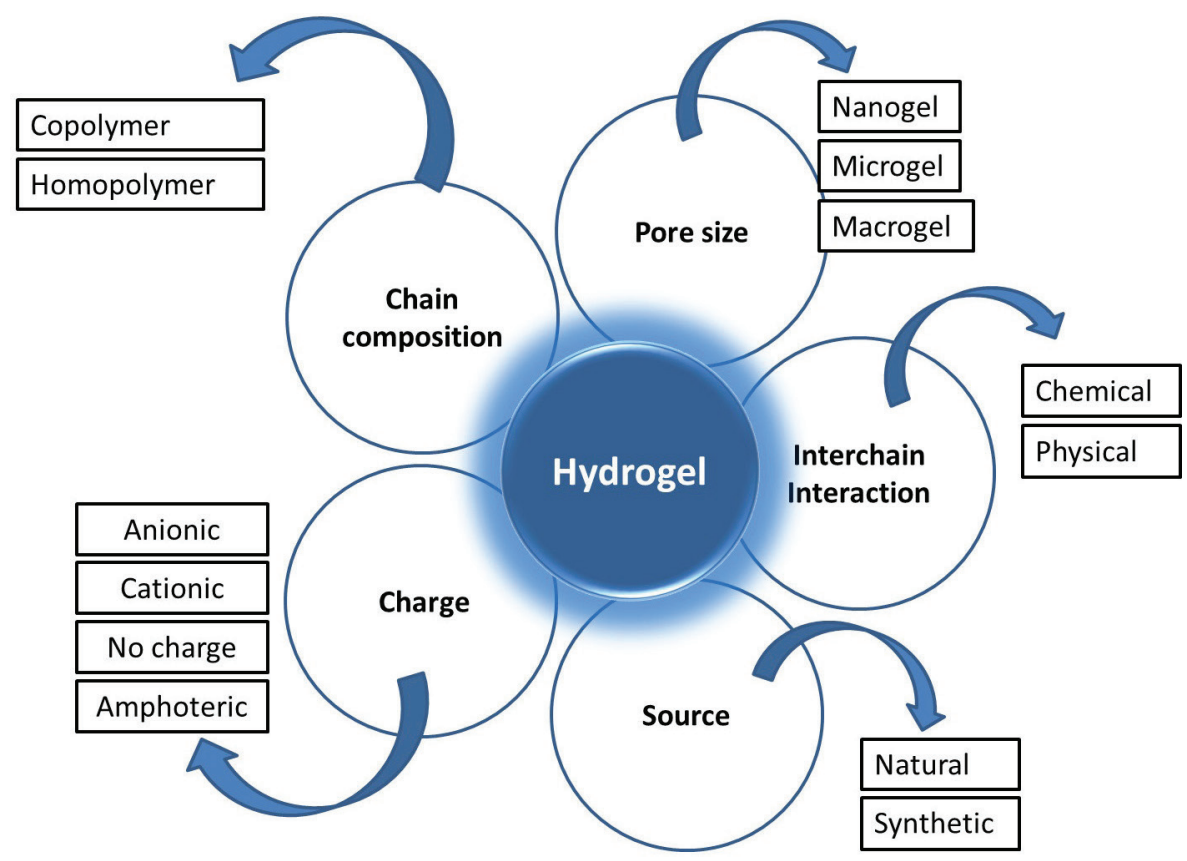

Figure 1. Chemical and physical aspects for the classification of polymer hydrogels.
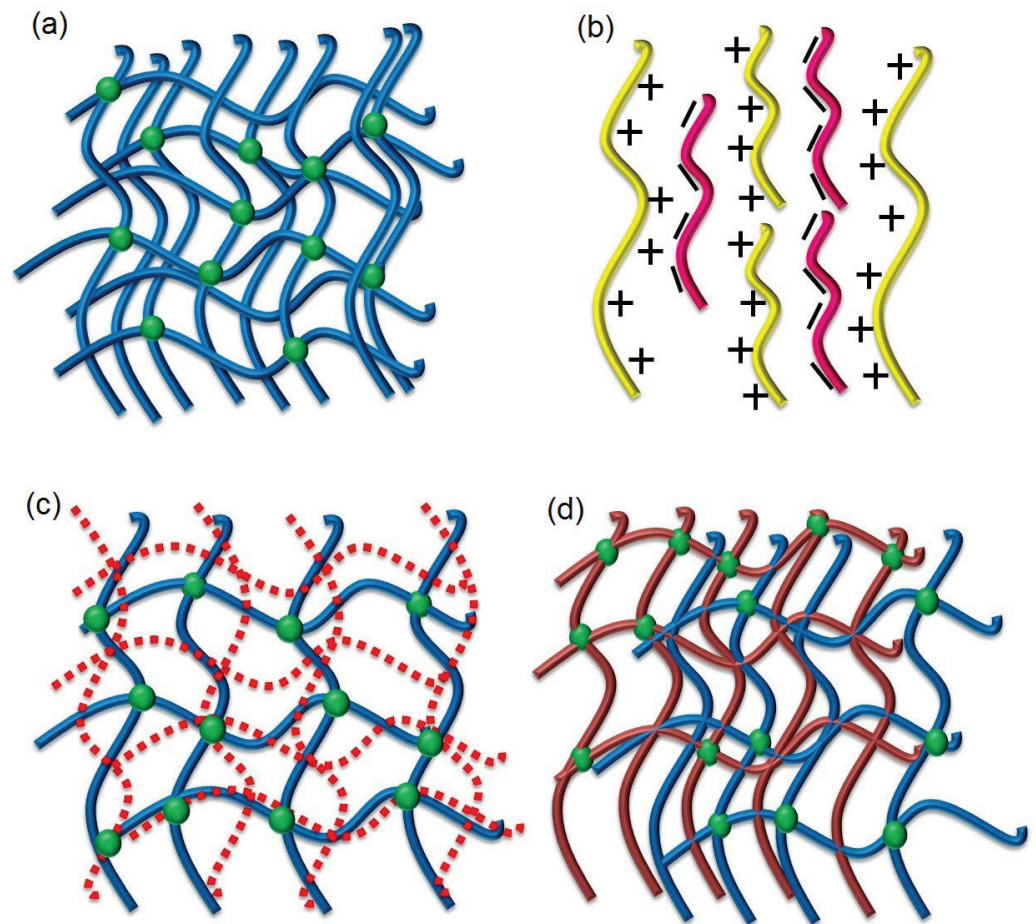

Figure 2. Schematic representation of (a) chemical hydrogels; (b) physical hydrogels; (c) semi- and (d) full-IPN. Green sphere: crosslinker; blue line: polymer chain A; red line: polymer chain B; yellow line: polycation; pink line: polyanion.

thermal fluctuations in a characteristic relaxation time (Néel relaxation time). In the absence of external magnetic field, the magnetization of MNP is in average zero because the time used to measure the magnetization is much longer than the relaxation time. Figure $3 \mathrm{~A}$ represents a typical behavior of permanent magnets (or large paramagnetic particles), where the magnetization (B, in tesla) is measured as a function of an applied $\mathrm{EMF}\left(\mathrm{H}\right.$, in $\left.\mathrm{A} \mathrm{m}^{-1}\right)$. A hysteretic behavior is clearly observed because some domains remain aligned in relation to the remanence; the positions (a) and (d) represent the magnetization saturation, (b) and (e) stand for remanence, (c) and (f) correspond to the coercivity in two opposite directions of applied EMF. In the case of SPIONs, represented in Figure 3B, as the EMF increases, 
the magnetic domains become aligned until achieving magnetic saturation moment. Upon decreasing the EMF value, the magnetization decreases, presenting no hysteresis or no coercivity. This is a typical behavior of SPIONs, ${ }^{24}$ which makes them attractive for diagnostics because in the absence of EMF there is no magnetization.

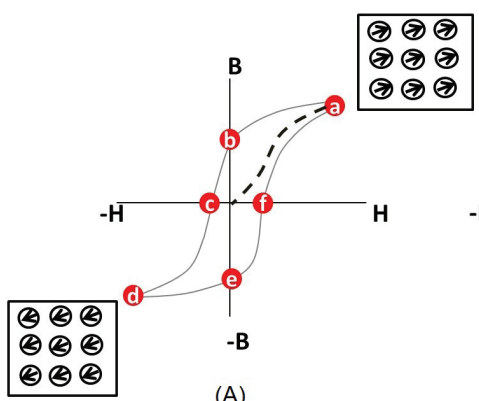

(A)

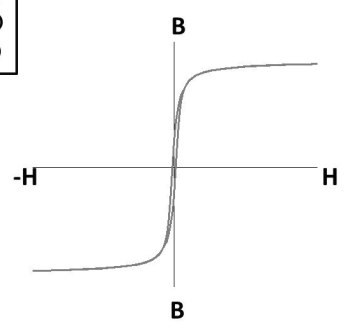

(B)
Figure 3. Schematic representation of magnetization (B, in tesla) as a function of $\operatorname{EMF}\left(\mathrm{H}\right.$, in $\left.\mathrm{A} \mathrm{m}^{-1}\right)$ for (A) permanent magnets (hysteretic behavior) and (B) SPIONs (non-hysteric behavior). In (A), the positions (a) and (d) represent the magnetization saturation; (b) and (e) stand for retentivity; (c) and (f) correspond to the coercivity in two opposite directions of applied EMF.

Considering the relaxation time as an exponential function of the grain volume, the probability of magnetic moment flipping decreases dramatically with the increase of particle size. When MNP are exposed to electromagnetic field with alternated direction, the magnetization flip dissipates thermal energy to the environment, causing the so-called magnetic hyperthermia, which has been largely used as medical therapy to damage malignant cells. ${ }^{25,26}$

The MNP might be injected directly into the tumor via a catheter and then heat is induced by alternating EMF. SPIONs have been used as contrast agents in MRI (magnetic resonance imaging) because gadolinium presents high toxicity, low blood flow and other collateral effects. ${ }^{27-29}$ MRI is a powerful non-invasive tool that associates the magnetic properties of hydrogen atoms present in the organism with an EMF and a transverse radio frequency pulse to produce images of human body, detection of tumor cells ${ }^{30}$ and localization of tissue-engineered implants. ${ }^{31}$

SPIONs with a medium size between 10 and $300 \mathrm{~nm}$ are clinically approved. ${ }^{27}$ However, harmful effects are related to iron concentration (maximal concentration of $10 \mu \mathrm{g} \mathrm{mL}^{-1}$ ), dosing and exposure time, as well as to interactions with proteins, changes in the hydrodynamic diameter of the particles and composition of particles coatings. ${ }^{32,33}$ Theranostic systems are interesting because they combine cancer therapy with diagnose to allow drug delivering and diagnostic imaging at the same time via targeting SPIONs encapsulated in magnetic hydrogels. ${ }^{34}$ Therefore, SPIONs together with hydrogels highlight as potential materials for biomedical applications. The synthesis, protection, functionalization, and applications of MNP for biomedical applications have been comprehensively described elsewhere. ${ }^{33,35}$

\section{Methods for the Preparation of Magnetic Hydrogels}

\subsection{Preparation of polymeric hydrogels}

There are several ways of synthesis of hydrogels such as physical crosslinking, chemical crosslinking, grafting polymerization, and radiation crosslinking. ${ }^{36}$ Physical crosslinking methods produce polymer chains weakly bonded, whereas the chemical crosslink requires the covalent attachment of chains by bi- or multifunctional molecules (crosslinkers). In comparison to physical hydrogels, chemical hydrogels have advantages as improved mechanical properties and chemical stability. ${ }^{37}$ However, unreacted residual crosslinkers should be removed (by rinsing, for instance) and toxic crosslinkers, such as epichlorohydrin, ${ }^{38}$ glutaraldehyde ${ }^{39}$ or $\mathrm{N}, \mathrm{N}$-methylenebisacrylamide ${ }^{40}$ should be avoided.

\subsubsection{Physical crosslinking}

Physical crosslinking stems from hydrogen bonding, hydrophobic interaction, van der Waals forces or ionic interactions among the polymer chains. ${ }^{41,42}$ Methods such as heating or cooling a polymer solution, maturation or aggregation from heat, ${ }^{43}$ stereocomplexation ${ }^{44}$ and freeze-thaw cycles may be used to prepare physical gels. Repetitive freeze-thaw processes favor microcrystals formation in the polymer structure, have no toxicity issues and do not generate harmful chemical residues ${ }^{45}$ Charged polymers can be crosslinked in presence of multivalent ions of opposite charge by electrostatic interaction; ${ }^{46}$ one classical example is the gelation of alginate in the presence of $\mathrm{Ca}^{2+}$ ions. Gelatin is an example of physical hydrogel from our everyday life formed by hydrogen bonds among the macromolecules; it is stable under low temperature, but at high temperature, the $\mathrm{H}$ bonds are disrupted, and the gel structure is lost.

\subsubsection{Chemical crosslinking}

For the production of chemical hydrogels, the most important methods are radical polymerization, condensation reaction, grafting, high-energy radiation and enzymatic reaction. In chemical crosslinking, polymers chains are crosslinked by bi- or multifunctional molecules, such as boric acid ${ }^{47}$ citric acid ${ }^{48}$ glutaraldehyde, ${ }^{49}$ divinyl sulfone, ${ }^{50}$ glyoxal ${ }^{51}$ and ethylene glycol di-methacrylate..$^{52}$ 
Grafting method uses high-energy radiation ${ }^{53}$ or chemical agent $^{54}$ to initiate the polymerization process. Crosslinking catalyzed by enzymes is interesting because the chemical reactions may take place under mild conditions. ${ }^{55}$ In radical polymerization, crosslinkers and initiators are added to the polymer solution to produce hydrogels quickly, under mild conditions of temperature and pressure. ${ }^{56,57}$

\subsection{Preparation of magnetic hydrogels}

Magnetic hydrogels refer to the incorporation of MNP into the polymeric gel. Iron based MNP can be synthesized by thermal decomposition/reduction, coprecipitation, hydrothermal synthesis, micelle synthesis, and laser pyrolysis. ${ }^{58}$ Co-precipitation, the simplest and cheapest method, is indicated in equation $1,^{59}$ the $\mathrm{pH}$ of aqueous $\mathrm{Fe}^{2+}: \mathrm{Fe}^{3+}$ (1:2) salt solutions is adjusted to 10 by the dropwise addition of $\mathrm{NH}_{4} \mathrm{OH}$, followed by heating (ca. $75^{\circ} \mathrm{C}$ ) for $30 \mathrm{~min}$ or sonication at room temperature for $10 \mathrm{~min} .{ }^{60}$ The size, shape, and composition of MNP are influenced by the type of reactants and reaction conditions. Controlling synthetic route conditions and addition of stabilizers can increase the number of monodisperse particles. ${ }^{58,60}$

$$
\mathrm{Fe}^{2+}+2 \mathrm{Fe}^{3+}+8 \mathrm{OH}^{-} \rightarrow \mathrm{Fe}_{3} \mathrm{O}_{4}+4 \mathrm{H}_{2} \mathrm{O}
$$

\subsubsection{Blending method}

Blending method is advantageous because it is fast, simple and cost-effective. In the blending method, firstly MNP are synthesized, as for instance by equation 1 and then mixed with the polymer solution by mechanical stirring, resulting in physical interactions among polymer chains and MNP. Then, a crosslinker might be added to the system to promote in situ polymer chains crosslinking; the MNP remain physically entrapped into the network ${ }^{61-64}$ (Figure 4a). Alternatively, the synthesis of MNP and crosslinking of polymer chains might be done separately. Then, the hydrogels are immersed in the MNP dispersion to promote physical interaction among them (Figure 4a). After that, the hydrogels are rinsed in order to remove the excess of MNP. ${ }^{65}$ Keeping the hydrogels immersed into MNP dispersions for long period of time might increase the amount of physically bound MNP. However, for biomedical applications it is important to assure that the MNP are not leached from the hydrogels due to cytotoxicity. For instance, xanthan scaffolds containing less than $1 \%$ of magnetite was suitable for biomedical application with appropriated levels of magnetization and absence of cytotoxicity. ${ }^{66}$

(a)

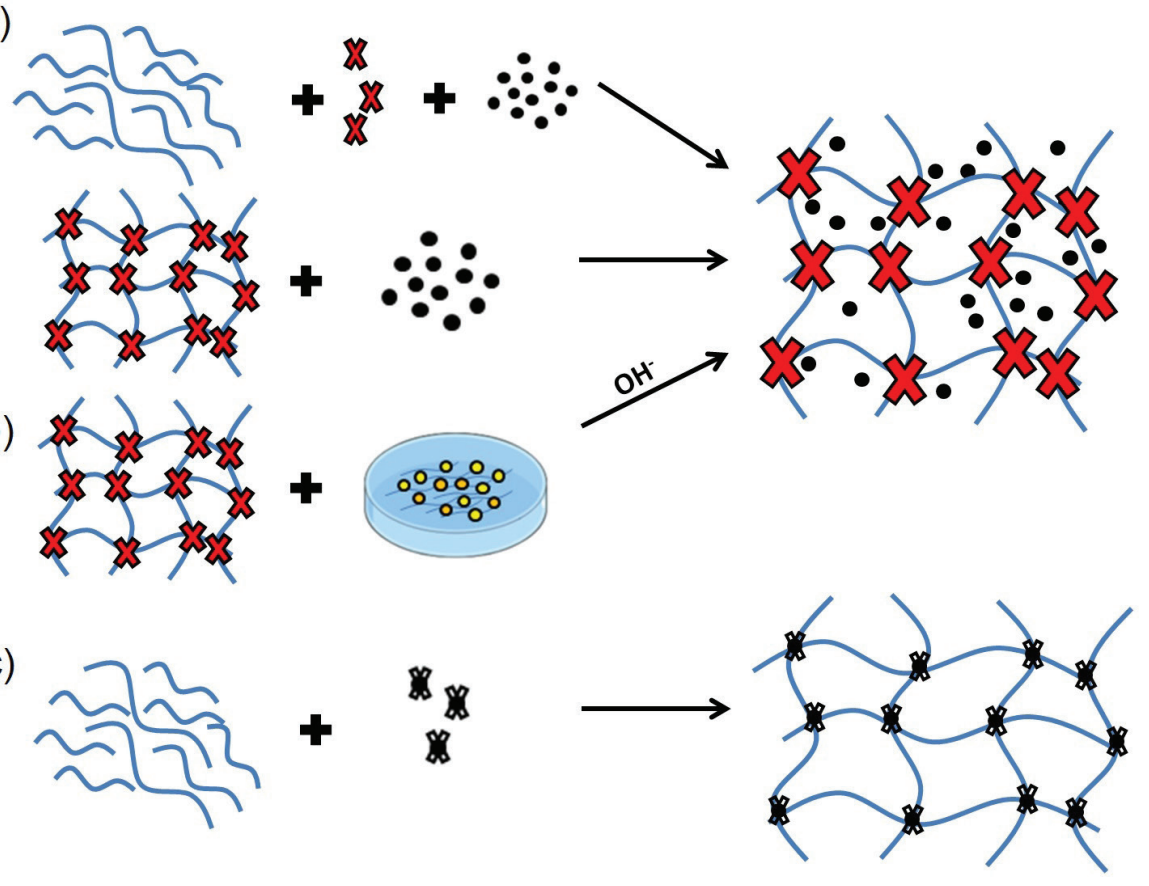

(c)

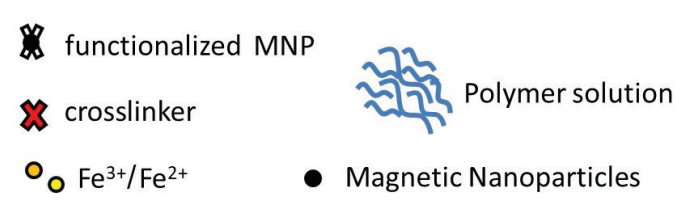

Figure 4. Schematic representation of methods to prepare magnetic hydrogels. (a) Blending; (b) in situ co-precipitation and (c) grafting method. MNP are represented by black spheres. Red and white X symbols represent crosslinker and functional groups, respectively. 


\subsubsection{In situ co-precipitation}

In the in situ co-precipitation, hydrogels are immersed in the aqueous solution of $\mathrm{Fe}^{2+}$ and $\mathrm{Fe}^{3+}$ ions until achieving swelling equilibrium, ${ }^{67}$ as depicted in Figure $4 \mathrm{~b}$. Then, hydrogels are soaked in a precipitant medium, such as $\mathrm{NaOH}^{68}$ and $\mathrm{NH}_{3} \cdot \mathrm{H}_{2} \mathrm{O},{ }^{69}$ to promote the formation of MNP as indicated in equation 1. It is a simple method and provides high MNP loading into the hydrogels, making them dark and with superparamagnetic properties. ${ }^{70}$ However, negatively charged hydrogels can form complexes with $\mathrm{Fe}^{2+}$ and $\mathrm{Fe}^{3+}$ ions, decreasing the amount of $\mathrm{Fe}^{2+}$ and $\mathrm{Fe}^{3+}$ ions available for the co-precipitation. In addition, the crosslinking among the polymeric chains should be unstable under alkali medium; for instance, ester bonds might undergo hydrolysis at $\mathrm{pH}>10 .{ }^{59}$ Horst et al ${ }^{71}$ compared two approaches to produce ferrogels, blending and co-precipitation. The results indicated that ferrogels produced by co-precipitation loaded higher amount of MNP than those produced by blending.

\subsubsection{Grafting method}

In the grafting method, the MNP are modified to bring functionalities on the surface, which are able to interact or react with the polymer chains, as depicted in Figure 4c. ${ }^{63,72-74}$ For instance, $\mathrm{CoFe}_{2} \mathrm{O}_{4}$ particles modified with aminopropyl silane carry amino groups on the surface, which interact strongly with the matrix of carboxymethyl cellulose; the resulting magnetic hydrogel was efficient for drug release under alternating magnetic field. ${ }^{75,76}$ Covalent bonds among functionalized MNP and hydrogel network provide advantages such as the decrease of MNP leaching from the gel and the homogeneous distribution of the MNP in matrix..$^{59,73,76}$ It is worth mentioning that the MNP functionalization step is a costly and complex process. In addition, polymeric network should have active sites to interact with the functional groups on the MNP surface. ${ }^{59}$

\subsection{Characterization of magnetic hydrogels}

The characterization of magnetic hydrogels usually comprises the determination of magnetic properties, electron microscopy, swelling degree, mechanical tests, infrared vibrational spectroscopy and rheology.

The superparamagnetic properties of MNP alone or embedded in the hydrogel can be accurately evaluated by a superconducting quantum interference device (SQUID) magnetometer. The magnetization curves yield the magnetic saturation and coercivity, as indicated in Figure 3. Transmission electron microscopy (TEM) is important for the determination of MNP size. As aforementioned, the superparamagnetic properties depend on the size of magnetic particles. Scanning electron microscopy (SEM) is generally used to analyze the hydrogels morphology. First, the hydrogels must be freeze-dried and then coated with a thin layer of conductive material. Upon freezing, the crystallization of ice causes volume expansion, destroying the nanopores. In order to avoid this effect, water can be gradually exchanged by tert-butanol or other alcohol, since it does not expand upon freezing. SEM images can be complemented by energy dispersive X-ray spectroscopy (EDS) for the mapping of iron and iron distribution in the sample.

The swelling degree (SD) of hydrogels is generally determined by gravimetry. The weight of swollen hydrogel divided by the weight of dried hydrogel yields the SD value. The more hydrophilic is the polymeric matrix, the higher is the SD value. The experimental procedure can be very simple, requiring only an analytical balance. The freeze-dried matrix is weighed and immersed in water to swell until the hydrogel volume remains constant. Then, the excess of water is removed by filter paper and the swollen hydrogel is weighed again. High resolution tensiometers allow determining the mass of water uptake by the dried matrix as a function of time. In this case, the dried sample is weighed and placed inside a measuring cylinder with porous bottom, which is connected to the measuring unit. A vessel containing water approaches towards the cylinder until the cylinder touches the liquid surface. At this point, water penetrates into the sample by capillarity, causing steady increase of mass. The increase of mass is recorded automatically as a function of time until achieving a mass value corresponding to saturation "plateau". 48

Tensile and/or compression tests are important to gain insight about the physical stability of hydrogels under stress. They can be performed for freeze-dried and swollen hydrogels. In the former, the Young (E) modulus is determined from the slope of stress-strain curves; the E values depend on the density ( $\rho$ ) of dried matrix and on the type of pore, for instance, in the case of porous matrices with open cells, E scales with $\rho^{\mathrm{m}}$, where $\mathrm{m}$ vary from 1.5 to 2.0. ${ }^{77}$ The larger the E value, the stiffer is the matrix. In the latter, the compressive force required to deform the swollen hydrogels by a given extent is evaluated. ${ }^{78}$

Infrared vibrational spectroscopy is particularly important in the case of chemical hydrogels because the presence of bands in the spectra, which might be assigned to chemical groups belonging to polymer chains and crosslinkers, yields a strong evidence for the chemical crosslinking. Spectra obtained for magnetic hydrogels might present absorption bands in the low wavenumber region $\left(<800 \mathrm{~cm}^{-1}\right)$, which are typical for $\mathrm{Fe}-\mathrm{O}$ stretching in magnetite, maghemite or hematite. ${ }^{79}$ 
Rheological characterization is particularly interesting for magnetic hydrogels that are designed for injectable formulations or for 3D printing. Extremely low or high viscosity gels are not suitable because they flow very quickly or very slowly, respectively. Ideally, the gel viscosity should be adjusted to provide the suitable flow rate for the desired application. For instance, it is easier to inject a gel through a small gage needle (high strain) if it presents shear thinning behavior. ${ }^{80}$ Polymer gels which exhibit sol-gel transition at body temperature are also interesting because at room temperature they have low viscosity, facilitating the injection through a small gage needle into animals, and at body temperature, they become gels. ${ }^{81}$ In the case of extrusion-based 3D printing, first the hydrogel or magnetic hydrogel is loaded into a syringe or reservoir with a relative large cross section area at low shear rate. Then, as the gel approaches the printer nozzle and during printing, the cross-section in the system decreases considerably and the shear rate increases. In this process, pseudoplastic or even thixotropic behavior of hydrogels helps optimizing the shear rate profile in the $3 \mathrm{D}$ printing nozzle and printing of smooth and bubble free hydrogels strands. ${ }^{82}$ As the hydrogel is released from the nozzle and deposited onto a surface, the shear rate becomes practically null. In order to obtain shape fidelity of the printed body, the hydrogels should quickly become stiffer under these conditions. In rheological terms this means that the gels recover their structure and assume a solid-like behavior, which can be characterized by either determining the yield stress (minimum stress to start flowing) or the viscoelastic moduli G' and G'. At this point, a given yield stress or a quick recovery of the elastic modulus G' is desirable because it helps keeping the printed shape during the hydrogels solidification. Particularly in the case of magnetic hydrogels, the increase in the content of MNP causes the increase of G' mainly due to the formation of large particle cluster. ${ }^{83}$

\section{Biomedical Applications of Magnetic Hydrogel}

Physical and chemical stimuli include changes in temperature, ${ }^{84}$ electric ${ }^{85}$ or magnetic field, ${ }^{86}$ light, ${ }^{87} \mathrm{pH}^{88}$ and ionic strength. ${ }^{89}$ Such stimuli can make drug release from responsive hydrogels more sustained. The presence of MNP in hydrogels makes them suitable for magnetically stimulated applications, as depicted in Figure 5. The concept of magnetically stimulated drug delivery was proposed by Langer and co-workers, ,90,91 where magnetoresponsive hydrogels of ethylene vinyl acetate were loaded with insulin. Since then new magnetic systems have been developed for biomedical applications, as detailed below.

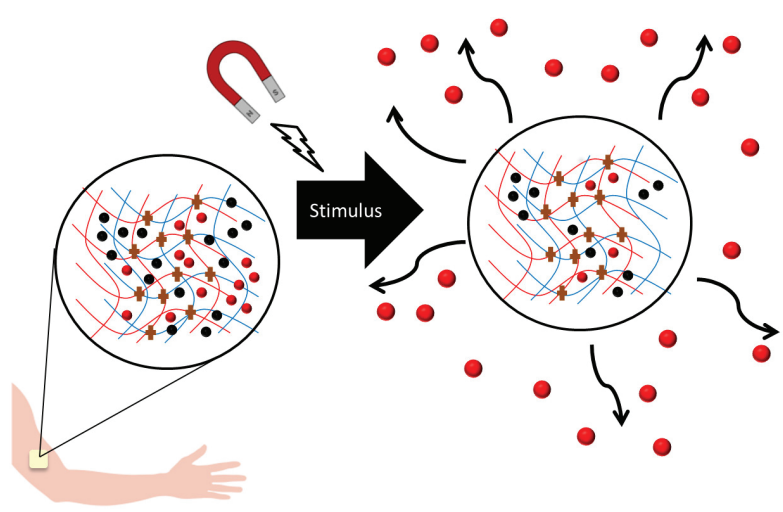

Figure 5. Schematic representation of drug delivery under stimulus of external magnetic field. The drug (red spheres) can be loaded in magnetic hydrogels, which can be shaped as transdermal patches or injected.

\subsection{Drug delivery}

Responsive hydrogels have been applied as drug delivery systems due to their ability to swell, tunable viscoelastic properties, thermoreversible gelation, porous structure and biocompatibility. ${ }^{87,92}$ Triggering drug release processes have several advantages over conventional drug administration because they maintain an effective concentration of released drug for prolonged time, minimizing side effects. Moreover, the possibility to guide the drug loaded magnetic hydrogel by an EMF reduces the delivery of drug to off-target sites and its deleterious effects in the organism. ${ }^{93-96}$

Table 1 presents examples of magnetically stimulated drug release systems. Some of them can be used to the delivery of drugs to the central nervous system due to their capability of being injected into the intrathecal space. ${ }^{107}$ However, drug release in brain is yet challenging due to the blood brain barrier. ${ }^{108}$ Antiparkinsonian drugs such as levodopa and dopamine were entrapped into alginate and xanthan gum in order to evaluate the drug release in vitro and neural cell response. The EMF of $0.4 \mathrm{~T}$ stimulated the release of levodopa from magnetic hydrogels, indicating a suitable system to sustained-release of drug. ${ }^{99}$ Kondaveeti et al..$^{98}$ reported dopamine increase from 24 to $33 \%$ under the stimulus of EMF. Hydrogel-based hydrophobic drug delivery is carried out by secondary vehicles encapsulated into the hydrogel such as polymeric micelle and surfactants. However, this way can cause low drug loaded amount into polymeric network. Thus, the employment of secondary vehicles is able to overcome issues of hydrophobic drug loaded in the gel and improve the delivery of hydrophobic drug into aqueous medium. ${ }^{109,110}$ One promising strategy is the delivery of hydrophobic drug in the form of nanoparticles embedded in hyaluronic acid hydrogels ${ }^{110}$ or from hybrid beads of alginate, double hydroxides and magnetic graphite nanoparticles. ${ }^{111}$ 
Table 1. Magneto-responsive hydrogels in drug delivery systems (1.0 tesla $=10,000$ gauss)

\begin{tabular}{|c|c|c|c|c|}
\hline Hydrogel & Synthesis route & Drug & Stimulus & Reference \\
\hline Hemicellulose gel & in situ co-precipitation & BSA & permanent magnet & 86 \\
\hline $\mathrm{CS}$ & in situ co-precipitation & adriamycin/rifampicin & permanent magnets, $0.4 \mathrm{~T}$ & 97 \\
\hline Alginate bead & in situ co-precipitation & dopamine & $\begin{array}{l}\text { Nd magnet discs } \\
(1 \mathrm{~cm} \text { diameter and } \\
1.5 \mathrm{~mm} \text { thick }), 0.4 \mathrm{~T}\end{array}$ & 98 \\
\hline $\begin{array}{l}\text { Transdermal patches alginate/ } \\
\text { xanthan }\end{array}$ & in situ co-precipitation & levodopa & $\begin{array}{l}\mathrm{Nd} \text { magnet discs } \\
(1 \mathrm{~cm} \text { diameter and } \\
1.5 \mathrm{~mm} \text { thick }), 0.4 \mathrm{~T}\end{array}$ & 99 \\
\hline $\begin{array}{l}\text { Beads of } \kappa \text {-carrageenan/ } \\
\text { CMC-CS }\end{array}$ & in situ co-precipitation & diclofenac sodium & $\begin{array}{c}\text { alternating EMF apparatus } \\
\text { with frequency of } 350 \mathrm{kHz} \text {, } \\
100 \text { and } 300 \mathrm{G}\end{array}$ & 100 \\
\hline CMC/acrylamide & blending & diclofenac sodium & 100 and $300 \mathrm{G}$ & 101 \\
\hline CS/GU/MA gel & in situ co-precipitation & curcumin & $0.35 \mathrm{~T}$ & 78 \\
\hline PVA thin film & in situ co-precipitation & ciprofloxacin & $\begin{array}{l}\text { in vitro release experiments } \\
\text { under EMF of } 75 \mathrm{G}\end{array}$ & 102 \\
\hline Lipid microcapsule & blending & $\mathrm{DOX}$ or $\mathrm{CF}$ & $\begin{array}{l}\text { EMF was applied by magnetic } \\
\text { field coils of } 2 \mathrm{kHz} \text { and } \\
20 \mathrm{mT}\end{array}$ & 103 \\
\hline Bead of alginate/CS & in situ co-precipitation & insulin & $\begin{array}{l}\text { discs of permanent magnet } \\
(\mathrm{NdFeB}, 10 \times 10 \mathrm{~mm})\end{array}$ & 104 \\
\hline Nanoparticle of starch & in situ co-precipitation & cisplatin & $\begin{array}{l}\text { in vitro drug delivery, } \\
300 \mathrm{G}\end{array}$ & 105 \\
\hline $\begin{array}{l}\text { Transdermal patches of } \\
\text { xanthan }\end{array}$ & blending & amoxicillin & permanent magnets of $\mathrm{Nd}$ & 106 \\
\hline
\end{tabular}

BSA: bovine serum albumin; CS: chitosan; CMC-CS: carboxymethyl chitosan; EMF: external magnetic field; CMC: carboxymethyl cellulose; GU: gum arabic; MA: maltodextrin; PVA: poly(vinyl alcohol); DOX: doxorubicin hydrochloride; CF: carboxyfluorescein.

The drug release behavior and the porosity of the ferrogels can be affected by turning on and off the magnetic field. ${ }^{112}$ Generally, in the absence of external magnetic field (off) the drug diffusion to the medium depended mainly on the interactions among drug and carrier. If the interactions among drug molecules and matrix are weak, the drug molecules tend to diffuse rapidly to the medium (burst effect). On the other hand, if the interactions among matrix and drug molecules are strong, the release tends to be slow. In the presence of external magnetic field (on), the magnetic moments of MNP become aligned with the magnetic field rather than randomly oriented. Alternating from on to off mode, induces an oscillatory movement of MNP, causing vibrations in the crosslinked polymer chains, which stimulate the drug release to the medium. ${ }^{104,113}$ Moreover, MNP can respond resonantly to an alternated magnetic field, producing heat, this is the so-called magnetic hyperthermia. This phenomenon might decrease the interactions between polymer gel and drug, favoring the drug release. ${ }^{95}$

\subsection{Tissue engineering}

Tissue engineering and regenerative medicine aim at restoring, maintaining or improving tissue functions. Cell proliferation and differentiation, cell implantation, and delivering of tissue inducing substances, as growth factors (GF), are important issues in this field. Porous 3D biomaterials or scaffolds allow regular transport of gases and nutrients, favoring cell adhesion, growth and differentiation and the regeneration of damaged tissues. ${ }^{114,115}$ Hydrogels of polysaccharides and/or proteins are attractive to develop scaffolds due to their similarities with the extracellular matrix (ECM), biocompatibility, biodegradability and chemical versatility. ${ }^{116}$

Hybrid hydrogels are those composed of natural and synthetic macromolecules or macromolecules and inorganic particles. They are also promising materials in the development of bio-artificial tissue of corneas, oral mucosa, skin, cartilage and abdominal-wall. ${ }^{17}$ However, one should note that the viscoelastic modulus of scaffolds plays a crucial role on the cell response. For instance, for osteogenic differentiation, rigid (modulus ca. $30 \mathrm{kPa}$ ) scaffolds are indicated, whereas for neuronal differentiation soft (modulus ca. $1 \mathrm{kPa}$ ) matrices are preferable. ${ }^{118}$

Magneto-responsive hydrogels have been developed to enhance the scaffolds functionalities and to stimulate 
cellular responses under external magnetic field. ${ }^{11,59,119}$ For instance, GF can be loaded into the magnetic hydrogels; their delivery to the cell culture medium can be controlled by applying intermittent or continuous magnetic field.

Regardless of the method of preparation, the suitability of the magnetic scaffolds for cell proliferation and differentiation must be preliminarily checked, as detailed elsewhere. ${ }^{120}$ Briefly, (i) the scaffolds integrity should last during the cell culture process; (ii) the scaffolds should resist to the sterilization method (UV radiation, $\gamma$-irradiation, ethylene oxide or ethanol $70 \% \mathrm{v} / \mathrm{v}$ ) and (iii) the cell viability on the scaffolds should be determined by counting the number of viable cells after 24 and $48 \mathrm{~h}$ contact with the scaffolds, in order to evaluate the scaffold cytotoxicity. If the scaffolds are suitable following the aforementioned criteria, the next step is the determination of cell growth curve over one week or longer and cell differentiation, particularly in the case of stem cells.

The evaluation of cytotoxicity is crucial for all biotechnological applications. Patil et al. ${ }^{121}$ compiled results about the cytotoxicity of SPIONs for different cells. Most studies indicate that SPIONs exhibit no toxicity at concentration lower than $0.1 \mathrm{mg} \mathrm{mL}^{-1}$; ${ }^{122}$ in fact, there are commercial products approved by the U. S. Food and Drug Administration, such as Feridex I.V.®, an intravenous injectable formulation of SPIONs and dextran. The toxic effects of SPIONs, both coated and uncoated, stem from their passive diffusion to the cell interior, where they are enzymatically degraded to $\mathrm{Fe}^{2+}$ ions; the $\mathrm{Fe}^{2+}$ ions generate reactive oxygen species (ROS) due to redox cycles. ROS can induce oxidative stress in membranes and harm DNA, affecting cell signaling pathways. ${ }^{123}$

Table 2 shows examples of magnetic scaffolds applied for different cell types, in vitro or in vivo, under magnetic stimulation. The experimental results clearly show that regardless of the cell type, static EMF and pulse electromagnetic fields of weak and strong intensities exert beneficial effects on cell behavior, being the increase of cell proliferation the most frequent observation. It is interesting because many of the magnetic hydrogel listed in Table 2 were prepared under different conditions, resulting in scaffolds with different surface energy, stiffness, porosity and surface anisotropy.

Understanding all mechanisms related to the cell behavior under the magnetic stimuli is still challenging due to the complex intracellular signal transduction pathways. However, some mechanisms are well established. For instance, in the case of osteoblasts, the cell-matrix interactions mediated by integrins, bone morphogenetic protein (BMP)-2 gene expression and $\mathrm{p} 38$ phosphorylation were substantially activated under static EMF. ${ }^{127,137}$ Another important issue is related to magneto mechanical effects on the cell-matrix interactions. Under exposition to an external magnetic field, the magnetic poles of MNP tend to orientate to field direction, causing scaffold deformation. If the EMF is alternated, the flipping might cause vibrations and heat. The mechanical movements of small amplitude can open the mechanosensitive ion channels of cell membranes of adhered cells, favoring the $\mathrm{Ca}^{2+}$ ions influx, an important signaling step; this is the so-called magnetomechanical effect. ${ }^{138,139}$ The increase of $\mathrm{Ca}^{2+}$ ions influx in cells cultivated under magnetic stimuli was evidenced by inductively coupled plasma atomic emission spectroscopy (ICP-AES) ${ }^{60}$ potentiometric microsensor selective for $\mathrm{Ca}^{2+}$ ions $^{64}$ and calcium fluorescence. ${ }^{134}$ Interestingly, Tay et al. ${ }^{134}$ observed that the $\mathrm{Ca}^{2+}$ influx did not depend on temperature changes, confirming that hyperthermia alone could not favor ion channels opening. Other hypotheses to explain the increased cell proliferation under magnetic stimuli consider that MNP might have ability to diminish intracellular $\mathrm{H}_{2} \mathrm{O}_{2}$ through intrinsic peroxidase-like activity ${ }^{140}$ or that MNP can accelerate cell cycle progression, which may be mediated by the free iron $(\mathrm{Fe})$ released from lysosomal degradation. ${ }^{141}$

In the case of injectable magnetic hydrogels, one might concern about the fate of magnetic hydrogels after injection. Most of the matrices used in the magneto-responsive materials are biodegradable, but the MNP are not. Considering that the polymer matrix undergoes relatively slow degradation, the release of MNP is also expected to be slow; keeping the amount of MNP implanted tissue at low level. After injection of magnetic hydrogels in rats, the MNP were detected in liver and spleen and part of them was excreted. ${ }^{142}$

In vitro cell culture systems are generally based on multiwall plates or Petri dishes, which are considered 2D substrates. After the desired proliferation/differentiation, the cells are easily removed from the supports. The 2D cell culture has been used not only to study different cell types in vitro but also to design and test new drugs. However, the results observed from 2D cell culture could not accurately represent the rich environment and complex processes observed in vivo. Thus, the $3 \mathrm{D}$ cell culture became attractive because it is closer to the microenvironment that cells experience in vivo, particularly the cell-cell and cell-ECM interactions, which are very important for cell signaling. ${ }^{143}$ The transition from 2D to 3D cell culture is a relevant step forward to the personalized medicine, where the treatment involves tissue regeneration using patients' own cells. There are different approaches for the 3D cell culture; the cells are brought together with ECM and nutrients in rotational/ agitation or hanging drops, ${ }^{144}$ microfluidic ${ }^{145}$ or magnetic 
Table 2. Magneto-responsive hydrogels in tissue engineering applications

\begin{tabular}{lcccc}
\hline Scaffold & Cell type & Stimuli & Remark & Reference \\
\hline Type II collagen & $\begin{array}{c}\text { bone marrow derived } \\
\text { mesenchymal st }\end{array}$ & $\begin{array}{c}\text { N42 neodymium magnet, } \\
\text { diameter of 22 and } \\
25 \mathrm{~mm} \text { high }\end{array}$ & $\begin{array}{c}\text { EMF was used to guide the scaffold to } \\
\text { the exact cartilage defect site remotely }\end{array}$ & 124 \\
\hline $\begin{array}{l}\text { HA/collagen, magnetization } \\
\text { ranging from 0.5 to } \\
1.7 \text { emu g-1 }\end{array}$ & $\begin{array}{c}\text { human bone marrow st, } \\
\text { in vitro }\end{array}$ & no EMF & $\begin{array}{c}\text { bone graft substitute, good cell } \\
\text { adhesion and proliferation }\end{array}$ & 125 \\
\hline
\end{tabular}

\begin{tabular}{|c|c|c|c|c|}
\hline $\begin{array}{l}\text { Fibrous PLA/HA electrospun } \\
\text { scaffolds, saturation } \\
\text { magnetization of } \\
0.049 \mathrm{emu} \mathrm{g}^{-1}\end{array}$ & $\begin{array}{l}\text { bone tissue-lumbar } \\
\text { transverse defect of } \\
\text { rabbits, in vivo }\end{array}$ & $\begin{array}{l}\text { scaffolds with static } \\
\text { magnets distributed along } \\
\text { the animal cage, magnetic } \\
\text { intensity from } 0.05 \text { to } \\
25 \mathrm{mT}\end{array}$ & accelerated bone tissue regeneration & 126 \\
\hline PCL and MNP & $\begin{array}{l}\text { mouse calvarium } \\
\text { osteoblasts, in vivo and } \\
\text { in vitro }\end{array}$ & $\begin{array}{l}\text { neodymium }\left(\mathrm{Nd}_{2} \mathrm{Fe}_{14} \mathrm{~B}\right) \\
\text { disc magnet } \\
(1 \mathrm{~mm} \text { thick } \times 15 \mathrm{~mm} \\
\text { diameter })\end{array}$ & $\begin{array}{l}\text { activation of integrin signaling } \\
\text { pathways and up-regulation of } \\
\text { bone morphogenetic protein- } 2 \text { and } \\
\text { phosphorylation of Smad } 1 / 5 / 8 ; \\
\text { promotion of expression of vascular } \\
\text { endothelial growth factor and } \\
\text { angiogenin- } 1 \text { genes and the formation } \\
\text { of capillary tubes }\end{array}$ & 127 \\
\hline $\begin{array}{l}\mathrm{HA} \text { doped with } \mathrm{Fe}^{2+} / \mathrm{Fe}^{3+} \text { ions } \\
\text { and collagen }\end{array}$ & $\begin{array}{l}\text { human osteosarcoma cell, } \\
\text { in vitro }\end{array}$ & static EMF $320 \mathrm{mT}$ & $\begin{array}{l}\text { improved cell proliferation compared } \\
\text { to the nonmagnetic control scaffold }\end{array}$ & 128 \\
\hline $\begin{array}{l}\text { Methacrylated chondroitin } \\
\text { sulfate enriched with platelet } \\
\text { lysate and MNP }\end{array}$ & $\begin{array}{l}\text { osteogenically } \\
\text { differentiated adipose- } \\
\text { derived stem cells and/ } \\
\text { or tendon-derived cells, } \\
\text { in vitro }\end{array}$ & static EMF $350 \mathrm{mT}$ & $\begin{array}{l}\text { impacted cell morphology and the } \\
\text { expression and synthesis of tendon- } \\
\text { and bone-like matrix }\end{array}$ & 129 \\
\hline Alginate/MNP & endothelial cells, in vitro & $\begin{array}{l}\text { AC magnetic field of } \\
10-15 \mathrm{G}\end{array}$ & $\begin{array}{l}\text { enhanced stimulation of endothelial } \\
\text { cells and organization into capillary- } \\
\text { like structures }\end{array}$ & 130 \\
\hline Fibrin $/ \mathrm{Fe}_{3} \mathrm{O}_{4}$ & cardiac cells, in vitro & oscillating $\mathrm{Nd}$ magnet & $\begin{array}{l}\text { increase in twitch force of contraction } \\
\text { in response to non-contact stretch }\end{array}$ & 131 \\
\hline Xanthan and MNP & fibroblast, in vitro & static EMF $400 \mathrm{mT}$ & $\begin{array}{l}\text { increase of cell proliferation and influx } \\
\text { of } \mathrm{Ca}^{2+} \text { ions }\end{array}$ & 60 \\
\hline $\begin{array}{l}\text { Xanthan, polypyrrole and } \\
\text { MNP }\end{array}$ & fibroblast, in vitro & static EMF $400 \mathrm{mT}$ & increase of cell proliferation & 132 \\
\hline $\begin{array}{l}\text { Chitosan/alginate multilayer } \\
\text { and MNP }\end{array}$ & fibroblast, in vitro & no EMF & higher cell proliferation rate & 133 \\
\hline Xanthan and MNP & neuronal cells, in vitro & static EMF $400 \mathrm{mT}$ & $\begin{array}{l}\text { increased cell proliferation and } \\
\text { differentiation to sensorial neurons }\end{array}$ & 66 \\
\hline $\begin{array}{l}\text { Starch coated MNP and } \\
\text { chitosan coated MNP }\end{array}$ & neuronal cells, in vitro & intermittent $150 \mathrm{mT}$ & starch coated MNP favored $\mathrm{Ca}^{2+}$ influx & 134 \\
\hline $\begin{array}{l}\text { Xanthan, alginate and MNP } \\
\text { loaded with levodopa }\end{array}$ & neuronal cells, in vitro & static EMF $400 \mathrm{mT}$ & $\begin{array}{c}\text { sustained release of levodopa and } \\
\text { differentiation to dopaminergic } \\
\text { neurons }\end{array}$ & 99 \\
\hline Xanthan/chitosan & NIH3T3 fibroblast & permanent magnet & $\begin{array}{l}\text { cell adhesion and proliferation of } \\
\text { NIH3T3 fibroblasts were favored }\end{array}$ & 135 \\
\hline Polycaprolactone & MC3T3-E1 & permanent magnet & $\begin{array}{l}\text { improved affinity of proteins and cells } \\
\text { for the scaffolds }\end{array}$ & 136 \\
\hline
\end{tabular}

st: stem cells; EMF: external magnetic field; HA: hydroxyapatite; PLA: poly(lactic acid); PCL: polycaprolactone; MNP: magnetic nanoparticles; AC: alternating current.

levitation ${ }^{146}$ based bioreactors. In the magnetic levitation cells are mixed with magnetic hydrogel and applied EMF using neodymium magnets on the top of the vials; the
MNP moved towards the magnets carrying the cells to the liquid/air interface. The levitated cells attracted other cells, favoring cell-cell interactions in solution. 


\subsection{Cancer therapy}

Paul Ehrlich proposed the use of "magic bullets" against illness; they should selectively deliver cytotoxic drugs to their designated targets (e.g. cancer cells). ${ }^{147}$ MNP were used as "magic bullets" because they served as agent contrast in the radiation therapy and they could be transported through vascular system under external magnetic field for cancer treatment. ${ }^{148}$ The first applications of MNP in chemotherapy appeared in the 70's, for example, for the delivery of cytotoxic drugs, as doxorubicin. ${ }^{149,150}$ Since then, MNPs have been widely used for cancer diagnostic and therapy. ${ }^{151-153}$

Conventional cancer therapy methods might cause side effects and death of healthy cells due to drug release in the off-target sites. Targeting approaches may be achieved by incorporating chemotherapeutics compounds into magnetic nanohydrogels, which can be guided by EMF to the specific tumor site to release the drug therein. For example, a magnetic thermosensitive hydrogel embedded with Bacillus Calmette-Guérin (BCG) was injected into the urinary bladder and guided to the tumor region by magnets for the treatment of bladder cancer. ${ }^{154}$ In this case, drug delivery under EMF was more efficient than the conventional surgical transurethral resection (TUR), which left about $40 \%$ of residual tumor. ${ }^{155}$ Dox (doxorubicin) was incorporated in chitosan (CS)/dipotassium orthophosphate hydrogels and applied as drug delivery in the osteosarcoma treatment; the results indicated the decrease of side effects in mice compared to Dox administration without carriers. ${ }^{156}$ The release of Dox/docetaxel from injectable hydrogels by magnetic hyperthermia induced stimuli displayed good biocompatibility, self-healing and injectable properties. ${ }^{157}$ Among cancer treatments, hyperthermia has been highlighted as a non-toxicity and non-invasive method. Magnetic hyperthermia refers to heating the cancer cells about $43-49{ }^{\circ} \mathrm{C}$ by applying alternated EMF. ${ }^{158}$ There are some advantages in the use of hyperthermia for chemotherapy such as (i) low toxicity; (ii) control of heating conditions; (iii) less invasive; (iv) injectable and (v) limited side effects. ${ }^{159,160}$ Poly(ethylene glycol)-based magnetic nanohydrogel particles were remotely heated upon exposure to an alternated EMF causing death of glioblastoma cells in vitro. ${ }^{161}$ The decrease of cancer cell viability was observed for graphene oxide-based hydrogel ${ }^{162}$ and chitosan nanofibers. ${ }^{163}$ Beyond killing of cancer cells, Dox/graphene-oxide/polyethylenimine allowed reducing the side effects on normal tissues. ${ }^{162}$ Table 3 summarizes the aforementioned examples of magnetic hydrogels for cancer therapy.

\section{Environmental Applications}

During the last decades, human activities have severely affected the environment. According to the European Environment Agency ${ }^{173}$ eight sectors influence the environment mostly namely, energy (production, conversion, and end-use), industry, transport, agriculture, forestry, fishing and aquaculture, tourism and recreation, and households. Particularly, the impact on water sources is a major public concern because life on Earth depends on them. The most common methods to treat contaminated water involve membrane separation, flocculation and coagulation, chemical oxidation, photocatalytic degradation (Fenton's reaction, for instance), and adsorption. Adsorption is simple, efficient, and costeffective. However, the materials and the process used for the adsorbent production should be as green as possible. Materials from renewable sources or biodegradable materials are good candidates. Moreover, the possibility of regeneration and multiple reuses of adsorbents are also very important to create sustainable processes. Operational methods that do not generate byproducts and that require low amount of energy are desirable. Adsorbents designed for specific interaction with some kind of pollutant are particularly attractive, if their synthesis does not generate large amounts of byproducts. For instance, hydrogels containing host molecules such as cyclodextrins $\mathbf{s}^{174,175}$ and calixarenes ${ }^{176}$ are interesting due to their hydrophobic cavities, which serve for the inclusion of hydrophobic pollutants.

The concentration of contaminants found in the water sample defines its quality. There are four categories of contaminants: (i) physical contaminants, which are sediments or compounds suspended in water; (ii) chemical contaminants, such as phosphorus compounds, salts of heavy metals, toxins, polycyclic aromatic hydrocarbons, estrogenic compounds and drugs; (iii) microbiological contaminants (viruses, bacteria, parasites) and (iv) radiological contaminants, as for instance, cesium, plutonium and uranium. ${ }^{177}$ Hydrogels are efficient adsorbents to remove the contaminants or to pre concentrate them, when they are present at a low concentration to be determined by a conventional analytical method. ${ }^{178}$ Generally, for the adsorption process, the adsorbent can be either packed in a fixed-bed column and the solution containing the contaminant flows through it or the adsorbent is stirred in a tank containing the contaminant. In the former, the formation of bubbles, irregular compaction and slow speed of solution flow and clogging are common problems. ${ }^{179}$ In the latter, such problems are avoided, but the adsorbent must be separated for recovery. Depending 
Table 3. Magneto-responsive materials in cancer therapy

\begin{tabular}{|c|c|c|c|c|}
\hline Material & Cell & Therapy & Remark & Reference \\
\hline PEG-MMA & $\begin{array}{l}\text { M059K glioblastoma } \\
\text { cells; in vitro }\end{array}$ & hyperthermia & $\begin{array}{l}\text { electromagnetic field induced } \\
\text { by a Taylor Winfield induction } \\
\text { power supply; solenoid of } 15 \mathrm{~mm} \\
\text { diameter, } 297 \mathrm{kHz} \text { and } 25 \mathrm{kA} \mathrm{m}^{-1}\end{array}$ & 161 \\
\hline $\begin{array}{l}\mathrm{PEG} / \mathrm{LA}-\mathrm{CS} \text { coated on the } \\
\text { surface of the biofunctionalized } \\
\mathrm{Fe}_{3} \mathrm{O}_{4}\end{array}$ & $\begin{array}{l}\text { in vitro: } \text { K562 cells; } \\
\text { in vivo: liver MRI }\end{array}$ & MRI & $\begin{array}{l}\text { in vivo: intravenously injected; } \\
\text { rats were exposed to } 1.5 \mathrm{~T} \\
\text { in vitro: MRI was carried out on } \\
\text { an AW } 4.2 \text { working station }\end{array}$ & 164 \\
\hline CS/GP & $\begin{array}{l}\text { intraperitoneal } \\
\text { injection to bladder, } \\
\text { in vivo }\end{array}$ & $\begin{array}{c}\text { drug release; release of } \\
\text { BCG }\end{array}$ & $\begin{array}{c}\text { EMF of } 4 \mathrm{kG} \text {; superior antitumor } \\
\text { efficacy }\end{array}$ & 154 \\
\hline $\begin{array}{l}\text { CS/GP; polyethylenimine- } \\
\text { modified } \\
\text { super-paramagnetic } \\
\text { graphene oxide }\end{array}$ & $\begin{array}{l}\text { in vitro: } \mathrm{MCF}-7 \text { cells; } \\
\text { in vivo: } \mathrm{S} 180 \text { tumor- } \\
\text { bearing mice }\end{array}$ & $\begin{array}{c}\text { hyperthermia/release of } \\
\text { DOX }\end{array}$ & EMF $488 \mathrm{kHz}, 20 \mathrm{~A}$ & 162 \\
\hline $\mathrm{CS} / \mathrm{PEG}$ & $\begin{array}{l}\text { in vitro: } \mathrm{L}-929 \text { cells } \\
\text { MDA-MB-231; in vivo: } \\
\text { MDA-MB-231 }\end{array}$ & $\begin{array}{l}\text { dual-drug-loaded magnetic } \\
\text { hydrogel: DOX/DTX }\end{array}$ & EMF $19.99 \mathrm{kA} \mathrm{m}^{-1}, 282 \mathrm{kHz}$ & 157 \\
\hline Dextran-coated SPIONs & $\begin{array}{l}\text { a rabbit with VX2 } \\
\text { malignant tumor. The } \\
\text { tumor was injected into } \\
\text { unilateral muscles }\end{array}$ & MRI & $\begin{array}{l}\text { intraperitoneal injection; magnetic } \\
\text { field intensity of } 1.5 \mathrm{~T}\end{array}$ & 165 \\
\hline PNIPAm & HeLa cells & delivery of DOX & Nd magnets & 166 \\
\hline CS nanofibers with $\mathrm{Fe}_{3} \mathrm{O}_{4}$ & Caco-2 cells & hyperthermia & alternated EMF & 163 \\
\hline SPION-NHs (SPION + PPZ) & $\begin{array}{l}\text { NIH3T3 mice fibroblast } \\
\text { cells and U-87 MG human } \\
\text { glioblastoma cells }\end{array}$ & MRI/hyperthermia & $\begin{array}{l}\text { in vivo: } \mathrm{EMF} 19.5 \mathrm{kA} \mathrm{m}^{-1} \text {, } \\
389 \mathrm{kHz}\end{array}$ & 167 \\
\hline Magnetic alginate microbeads & CFC-7 cells & $\begin{array}{c}\text { hyperthermia/release of } \\
\text { DOX }\end{array}$ & EMF, $700 \mathrm{kHz}$ and $27 \mathrm{mT}$ & 168 \\
\hline $\begin{array}{l}\text { Poly( } N \text {-isopropylacrylamide }) / \\
\text { CS }\end{array}$ & fibrosarcoma tumor & hyperthermia in vivo & $\begin{array}{c}\text { EMF: } 325 \text { or } 390 \text { Oe for } 30 \text { or } \\
20 \mathrm{~min}\end{array}$ & 169 \\
\hline $\begin{array}{l}\text { PEG-phospholipid with } \mathrm{Fe}_{3} \mathrm{O}_{4} \\
\text { nanoparticles/gellan gum }\end{array}$ & $\begin{array}{l}\text { RAW264.7; 4T1 cells } \\
\text { (breast tumor) - in vivo }\end{array}$ & $\begin{array}{l}\text { MRI/thermo- } \\
\text { chemotherapy/release of } \\
\text { PTX and DOX }\end{array}$ & $\begin{array}{c}\text { in vitro heat: a water-cooled } \\
\text { magnetic induction copper coil } \\
\text { with } 410 \mathrm{kHz} \text { and magnetic field } \\
\text { intensity of } 1.8 \mathrm{kA} \mathrm{m}^{-1} \text {; MRI was } \\
\text { carried out at } 7.0 \mathrm{~T} \text { with a } 35 \mathrm{~mm} \\
\text { birdcage coil }\end{array}$ & 170 \\
\hline $\begin{array}{l}\text { Magnetic alginate-chitosan } \\
\text { microspheres }\end{array}$ & MCF-7 cancer cells & $\begin{array}{c}\text { hyperthermia/release of } \\
\text { DOX }\end{array}$ & EMF: $40 \mathrm{kA} \mathrm{m}^{-1}, 265 \mathrm{kHz}, 10 \mathrm{~min}$ & 171 \\
\hline Magnetic HPMC & 4T1 cells & $\begin{array}{l}\text { hyperthermia/release of } \\
\text { DOX }\end{array}$ & $\begin{array}{c}\text { EMF: } 400 \mathrm{kHz} ; 7.2 \mathrm{~kW} \text {, coil } \\
\text { diameter: } 10 \mathrm{~cm}\end{array}$ & 172 \\
\hline
\end{tabular}

PEG-MMA: poly(ethylene glycol) methyl methacrylate; LA: lactobionic acid; CS: chitosan; MRI: magnetic resonance imaging; AW: Advantage Workstation; GP: $\beta$-glycerophosphate; BCG: Bacillus Calmette-Guérin; EMF: external magnetic field; DOX: doxorubicin hydrochloride; DTX: docetaxel; SPION: superparamagnetic iron oxide nanoparticle; PNIPAm: poly( $N$-isopropylacrylamide); PPZ: poly(organophosphazene); PTX: paclitaxel; HPMC: hydroxypropyl methylcellulose.

on the size of the adsorbent, sedimentation might be inefficient, and filtration or centrifugation might be costly and time consuming. Magnetic adsorbents offer the advantage of being easily separated from the solution upon the approximation of an external magnet. In comparison with other separation techniques, the magnetically assisted separation is noninvasive, fast, environmentally friendly and low cost (ca. US\$2.00 per Nd magnet ca. $30 \mathrm{~mm}$ diameter $\times 3 \mathrm{~mm}$ high). Magnetic hydrogels have been successfully applied for the removal of inorganic and organic contaminants, followed by magnetic separation and recovery, as exemplified in Table 4. In general, after magnetic separation, the adsorbent must be treated with organic solvent (in the case of organic 
pollutants) or with acid solution (in the case of metal ions) to promote desorption and adsorbent recovery. MNP are often resistant to organic solvents, but the contact with acid medium at very low $\mathrm{pH}$ can dissolve them. For this reason, the resistance of magnetic hydrogels under acid medium should be evaluated prior to adsorption/desorption

Table 4. Examples of magnetic hydrogels successfully applied for the removal of inorganic and organic contaminants. The number of adsorption/desorption cycles and removal or maximum adsorption capacity $\left(\mathrm{q}_{\max }\right)$ were indicated for each example

\begin{tabular}{|c|c|c|c|}
\hline Matrix & Contaminant & Remark & Reference \\
\hline $\begin{array}{l}\text { Acrylamidopropyl-trimethylammonium chloride } \\
\text { crosslinked with bisacrylamide and } \gamma-\mathrm{Fe}_{2} \mathrm{O}_{3} \\
\text { nanoparticles }\end{array}$ & $\mathrm{Cr}^{\mathrm{VI}}$ & $\begin{array}{l}\text { removal efficiency of } 98 \%, \\
20 \text { cycles }\end{array}$ & 180 \\
\hline $\begin{array}{l}\text { Beads of carboxylated cellulose nanofibrils, amine- } \\
\text { functionalized magnetite nanoparticles and PVA } \\
\text { blended CS }\end{array}$ & $\mathrm{Pb}^{\mathrm{II}}$ & $\mathrm{q}_{\max }=171 \mathrm{mg} \mathrm{g}^{-1}$, four cycles & 181 \\
\hline $\begin{array}{l}\text { Magnetite, } \mathrm{ZnO} \text { and dimethylacrylamide based } \\
\text { copolymers }\end{array}$ & $\mathrm{La}^{\mathrm{III}}, \mathrm{Co}^{\mathrm{II}}, \mathrm{Nd}^{\mathrm{III}}, \mathrm{Cu}^{\mathrm{II}}, \mathrm{Ni}^{\mathrm{II}}$ & $\begin{array}{l}\text { good selectivity toward } \mathrm{La}^{\mathrm{III}} \text { ions, } \\
\mathrm{q}_{\max }=58.8 \mathrm{mg} \mathrm{g}^{-1}, 6 \text { cycles }\end{array}$ & 182 \\
\hline $\mathrm{Fe}_{3} \mathrm{O}_{4}$ nanoparticles and peach gum polysaccharide & $\mathrm{Pb}^{\mathrm{II}}, \mathrm{Cd}^{\mathrm{II}}$ & $\begin{array}{c}\mathrm{q}_{\max } \text { values: } 277.0 \mathrm{mg} \mathrm{g}^{-1} \mathrm{~Pb}^{\mathrm{II}} \text { and } \\
141.4 \mathrm{mg} \mathrm{g}^{-1} \mathrm{Cd}^{\mathrm{II}}\end{array}$ & 183 \\
\hline Prussian Blue-embedded magnetic PVA hydrogel & ${ }^{137} \mathrm{Cs}$ & $\begin{array}{c}\mathrm{q}_{\max }=41.15 \mathrm{mg} \mathrm{g}^{-1} ; \text { selective } \\
\text { adsorption in the presence of } \mathrm{Na}^{+} \text {, } \\
\qquad \mathrm{Ca}^{2+}, \mathrm{Mg}^{2+}, \mathrm{K}^{+}\end{array}$ & 184 \\
\hline$\gamma-\mathrm{Fe}_{2} \mathrm{O}_{3}$ nanoparticles and alginate beads & $\mathrm{Cu}^{\mathrm{II}}$ & $\mathrm{q}_{\max }=159.2 \mathrm{mg} \mathrm{g}^{-1}$, five cycles & 185 \\
\hline PVA and $\gamma-\mathrm{Fe}_{2} \mathrm{O}_{3}$ hydrogels & $\mathrm{Cd}^{\mathrm{II}}$ and $\mathrm{Cu}^{\mathrm{II}}$ & $\begin{array}{l}\mathrm{q}_{\max } \text { values: } 71.3 \mathrm{mg} \mathrm{g}^{-1} \mathrm{Cd}^{\mathrm{II}} \text { and } \\
73.0 \mathrm{mg} \mathrm{g}^{-1} \mathrm{Cu}^{\mathrm{II}} \text {, five cycles }\end{array}$ & 186 \\
\hline PVA/laponite and $\mathrm{Fe}_{3} \mathrm{O}_{4}$ hydrogels & $\mathrm{Cd}^{\mathrm{II}}$ & $\begin{array}{c}\mathrm{q}_{\max }=0.10 \mathrm{mg} \mathrm{g}^{-1}, \text { at } \mathrm{pH} 2 ; \text { adsorption } \\
\text { capacity decreased } \\
\text { with pH increase }\end{array}$ & 187 \\
\hline$\gamma$ - $\mathrm{Fe}_{2} \mathrm{O}_{3}$ nanoparticles and alginate beads & $\mathrm{La}^{\mathrm{III}}$ & $\mathrm{q}_{\max }=123.5 \mathrm{mg} \mathrm{g}^{-1}$, five cycles & 188 \\
\hline $\begin{array}{l}\mathrm{Fe}_{3} \mathrm{O}_{4} \text { nanoparticles and chitosan - } \\
\text { co-poly(methylenebisacrylamide)-co-poly(acrylic acid) }\end{array}$ & $\mathrm{Pb}^{\mathrm{II}}, \mathrm{Cd}^{\mathrm{II}}$ and $\mathrm{Cu}^{\mathrm{II}}$ & $\begin{array}{l}\text { the addition of magnetic particles } \\
\text { reduced up to } 70 \% \text { of pristine } \\
\text { adsorption capacity }\end{array}$ & 189 \\
\hline PAM-grafted CS and silica-coated $\mathrm{Fe}_{3} \mathrm{O}_{4}$ nanoparticles & $\mathrm{Cu}^{\mathrm{II}}, \mathrm{Pb}^{\mathrm{II}}$ and $\mathrm{Hg}^{\mathrm{II}}$ & $\begin{array}{l}\text { at } 298 \mathrm{~K} \text { and } \mathrm{pH} 5.0 ; \mathrm{q}_{\max } \text { values: } \\
43.35 \mathrm{mg} \mathrm{g}^{-1} \mathrm{Cu}^{\mathrm{II}}, 63.67 \mathrm{mg} \mathrm{g}^{-1} \mathrm{~Pb}^{\mathrm{II}} \\
\text { and } 263.9 \mathrm{mg} \mathrm{g}^{-1} \mathrm{Hg}^{\mathrm{II}}, 5 \mathrm{cycles} \\
\text { regeneration with EDTA }\end{array}$ & 190 \\
\hline $\begin{array}{l}\text { CMS- } g \text {-PVI, PVA and } \mathrm{Fe}_{3} \mathrm{O}_{4} \text { crosslinked by } \\
\text { glutaraldehyde }\end{array}$ & $\begin{array}{l}\text { Crystal Violet }(\mathrm{CV}) \text { and } \\
\text { Congo Red }(\mathrm{CR}) \text { dyes; } \\
\mathrm{Pb}^{\mathrm{II}}, \mathrm{Cu}^{\mathrm{II}} \text { and } \mathrm{Cd}^{\mathrm{II}}\end{array}$ & $\begin{array}{c}\mathrm{q}_{\max } \text { values: } 65.00 \mathrm{mg} \mathrm{g}^{-1} \mathrm{~Pb}^{\mathrm{II}} \\
83.60 \mathrm{mg} \mathrm{g}^{-1} \mathrm{Cu}^{\mathrm{II}}, 53.20 \mathrm{mg} \mathrm{g}^{-1} \mathrm{Cd}^{\mathrm{II}} \\
83.66 \mathrm{mg} \mathrm{g}^{-1} \mathrm{CR} \text { and } 91.58 \mathrm{mg} \mathrm{g}^{-1} \\
\mathrm{CV} \text {, four cycles }\end{array}$ & 191 \\
\hline$p$-Sulfonated calix[4,6]arene derivatives and $\mathrm{Fe}_{3} \mathrm{O}_{4}$ & $\begin{array}{l}\text { benzidine, } p \text {-chloroaniline, } \\
\alpha \text {-naphthylamine }\end{array}$ & $\begin{array}{l}\text { highest adsorption capacity } \\
\text { at } \mathrm{pH} 3 \\
\end{array}$ & 192 \\
\hline $\begin{array}{l}\text { Novel sodium alginate supported tetrasodium } \\
\text { thiacalix[4]arene tetrasulfonate and } \mathrm{Fe}_{3} \mathrm{O}_{4}\end{array}$ & $\mathrm{Cu}^{\mathrm{II}}, \mathrm{Cd}^{\mathrm{II}}, \mathrm{Pb}^{\mathrm{II}}, \mathrm{Co}^{\mathrm{II}}, \mathrm{Ni}^{\mathrm{II}}$ and $\mathrm{Cr}^{\mathrm{III}}$ & $\begin{array}{c}\mathrm{q}_{\max } \text { values: } 11.1 \mathrm{mg} \mathrm{g}^{-1} \mathrm{Cu}^{\mathrm{II}} \\
18.9 \mathrm{mg} \mathrm{g}^{-1} \mathrm{Cd}^{\mathrm{II}}, 20.0 \mathrm{mg} \mathrm{g}^{-1} \mathrm{~Pb}^{\mathrm{II}} \\
15.0 \mathrm{mg} \mathrm{g}^{-1} \mathrm{Co}^{\mathrm{II}}, 13.5 \mathrm{mg} \mathrm{g}^{-1} \mathrm{Ni}^{\mathrm{II}} \\
\text { and } 15.5 \mathrm{mg} \mathrm{g}^{-1} \mathrm{Cr}^{\mathrm{III}}\end{array}$ & 193 \\
\hline $\mathrm{Fe}_{3} \mathrm{O}_{4}$ nanoparticles, xylan and poly(acrylic acid) & methylene blue & $\mathrm{q}_{\max }=438.6 \mathrm{mg} \mathrm{g}^{-1}$ & 194 \\
\hline Carboxymethyl- $\beta$-cyclodextrin and $\mathrm{Fe}_{3} \mathrm{O}_{4}$ & methylene blue & $\mathrm{q}_{\max }=277.8 \mathrm{mg} \mathrm{g}^{-1}$ & 195 \\
\hline $\begin{array}{l}\text { Hydroxypropyl methylcellulose crosslinked with citric } \\
\text { acid and EDTA impregnated with } \mathrm{Fe}_{3} \mathrm{O}_{4}\end{array}$ & $17 \alpha$-ethinyl estradiol & $\mathrm{q}_{\max }=0.6 \mathrm{mg} \mathrm{g}^{-1}$, five cycles & 196 \\
\hline Graphene oxide foam $\mathrm{Fe}_{3} \mathrm{O}_{4}$ & $\mathrm{Cr}^{\mathrm{VI}}$ & $\begin{array}{c}\mathrm{q}_{\max }=258.6 \mathrm{mg} \mathrm{g}^{-1}, \text { reduction } \\
\text { of } \mathrm{Cr}^{\mathrm{VI}} \text { to } \mathrm{Cr}^{\text {III }}\end{array}$ & 197 \\
\hline Chitosan and $\mathrm{Fe}_{3} \mathrm{O}_{4}$ & Acid Red 2 (dye) & $\mathrm{q}_{\max }=90.06 \mathrm{mg} \mathrm{g}^{-1}$ & 198 \\
\hline $\mathrm{CS}, \beta$-cyclodextrin and $\mathrm{Fe}_{3} \mathrm{O}_{4}$ & 2-aminopyridine & $\mathrm{q}_{\max }=46.5 \mathrm{mg} \mathrm{g}^{-1}$, five times & 199 \\
\hline
\end{tabular}

PVA: poly(vinyl alcohol); CS: chitosan; PAM: polyacrylamide; EDTA: ethylenediaminetetraacetic acid; CMS-g-PVI: carboxymethyl starch-g-polyvinyl imidazole. 
cycles, adjusting the medium $\mathrm{pH}$ to a value, which allows desorption without the dissolution of MNP. For instance, rinsing magnetic hydrogel with $5 \mathrm{~mol} \mathrm{~L}^{-1} \mathrm{HCl}$ caused the reduction of $50 \%$ in the original adsorption efficiency after five adsorption/desorption cycles, ${ }^{200}$ whereas $0.1 \mathrm{~mol} \mathrm{~L}^{-1}$ $\mathrm{HNO}_{3}$ led to the complete dissolution of the MNP already after three cycles. ${ }^{201}$ An alternative for the desorption of metal ions under acid medium is the addition of electrolytes, which have stronger affinity for the matrix than the ionic pollutant. For instance, the desorption of $\mathrm{La}^{\mathrm{III}}$ from magnetic alginate beads was successfully achieved by eluting with $0.050 \mathrm{~mol} \mathrm{~L}{ }^{-1} \mathrm{CaCl}_{2}{ }^{188}$

The adsorption efficiency of hydrogels tends to decrease in the presence of magnetite. ${ }^{189,196}$ This effect can be explained by the reduction of available adsorption sites, since many hydrogels carry hydroxyl and carboxyl groups that interact with $\mathrm{Fe}-\mathrm{OH}$ groups by $\mathrm{H}$ bonding. Thus, the amount of MNP in the hydrogel should be optimized in order to $(i)$ keep the adsorption capacity at an attractive level without leaching to the medium and (ii) provide enough magnetization to enable magnetically assisted separation. Literature reports ${ }^{202}$ indicate successful adsorbents with saturation magnetization ranging from ca. 4 to $60 \mathrm{emu} \mathrm{g}^{-1}$. One should notice that although magnetic hydrogels are excellent platforms for the removal of pollutants from water, they are not efficient in the separation of oil from water due to the high interfacial tension between oil and water phases. However, for the removal of oil spilt, magnetic hydrophobic 3D structures (foams, sponges, aerogels, cryogels, xerogels) have been prepared and applied successfully. ${ }^{202}$

\section{Future Trends and Challenges}

3D printing is an additive manufacturing method, which has been explored for different biomedical applications, such as the creation of dental implants or artificial organs or bioprinting of cells. For the manufacturing of tissues and organs there are two main routes: ( $i$ ) the tissue engineering route, where firstly the scaffold is printed and then it is combined with living cells and GF to create a biomimetic scaffold; and (ii) the direct assembly route, where cells and gel are printed together as 3D scaffolds. ${ }^{203}$ In situ 3D printing is already a reality in some hospitals ${ }^{203}$ and probably will become very popular in the near future because it enables the production of customized implants. Many materials used for the 3D printing of biomedical devices and scaffolds are soft materials, which turn into stiffer materials upon environmental stimulation (light radiation, temperature change, calcium release). The challenges related to this technology include the precise replication of pieces with very fine structures, as for instance, the vascular system, and pieces with surfaces that prevent bacterial adhesion. Another challenge is the change of the implant shape upon stimulation; this is the so-called 4D printing. ${ }^{15,204}$ 4D printing requires "smart materials", such as polymers with shape memory, self-healing polymers or composites, which respond timely to a given stimulus. Composites made of MNP and poly(dimethyl siloxane) were recently used for the 4D printing of magnetically responsive threedimensional (3D) structures; for instance, the wings of a butterfly were printed and could flap upon on/off EMF. ${ }^{205}$ This kind of technology points at the development of novel remotely controlled devices to perform different functions, ${ }^{206}$ making the future of magneto responsive hydrogels even more fascinating.

\section{Acknowledgments}

This work was supported by the Conselho Nacional de Desenvolvimento Científico e Tecnológico (CNPq grants 306848/2017 and 421014/2018-0) and São Paulo Research Foundation (FAPESP, grant 2018/13492-2). This study was financed in part by the Coordenação de Aperfeiçoamento de Pessoal de Nível Superior (CAPES), Brazil, finance code 001.

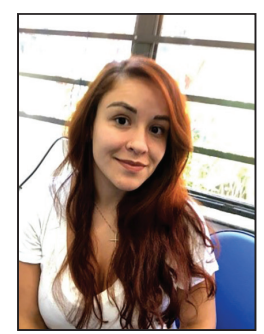

Emilli Caroline Garcia Frachini received her master's degree in Chemistry in 2018 at the Universidade Estadual de Londrina, UEL (Brazil). She worked in environmental risk assessment in watersheds, as Doce River (Minas Gerais) and Tibagi River (Paraná). Since July 2018, she is a PhD student in Prof Denise Petri's group, at the University of São Paulo, Brazil. Her current research focuses on the synthesis of magneto-responsive hydrogels for drug delivery and tissue engineering.

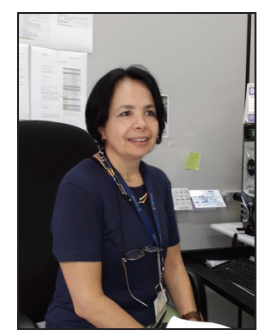

Denise Freitas Siqueira Petri is Professor of Chemistry at the Universidade de São Paulo, USP (Brazil). She received her master's (1990) and PhD (1992) degrees at Universidade Estadual de Campinas, UNICAMP (Brazil). She was postdoc at the Max Planck Institute for Polymer Chemistry, Mainz, Germany (1993-1995) and at the Polymer Institut, Universitaet Karlsruhe, Germany (1996-1997). She was appointed as Professor at the University of São Paulo in 1998. Since 2014, she is a Full Professor at the University of São Paulo. From March 
2014 to February 2018, she was the coordinator of the IQUSP Professional Master's Program in Chemistry and Biochemistry. Her interests are biopolymers at surfaces and interfaces and their interaction with nanoparticles, pollutants, proteins and cells.

\section{References}

1. Graham, T.; Philos. Trans. R. Soc. London 1861, 151, 183.

2. Mokrushin, S. G.; Nature 1962, 195, 861.

3. Lloyd, D. J.; Colloid Chem. 1926, 1, 767.

4. Kruyt, H. R.; Colloid Science, Volume II: Reversible Systems; Elsevier Publishing Company: New York, USA, 1949.

5. Wichterle, O.; Lim, D.; Nature 1960, 185, 117.

6. Kuhn, W.; Cell. Mol. Life Sci. 1949, 5, 318.

7. Ferreira, N. N.; Ferreira, L. M. B.; Cardoso, V. M. O.; Boni, F. I.; Souza, A. L. R.; Gremião, M. P. D.; Eur. Polym. J. 2018, 99, 117.

8. Ebara, M.; Kotsuchibashi, Y.; Narain, R.; Idota, N.; Kim, Y. J.; Hoffman, J. M.; Uto, K.; Aoyagi, T.; Smart Biomaterials; Springer: Japan, 2014.

9. Kost, J.; Wolfrum, J.; Langer, R.; J. Biomed. Mater. Res. 1987, 21, 1367.

10. Li, J.; Mooney, D. J.; Nat. Rev. Mater. 2016, 1, 16071.

11. Adedoyin, A. A.; Ekenseair, A. K.; Nano Res. 2018, 11, 5049.

12. Nandwana, V.; De, M.; Chu, S.; Jaiswal, M.; Rotz, M.; Meade, T. J.; Dravid, V. P.; Cancer Treat. Res. 2015, 166, 51.

13. Ozay, O.; Ekici, S.; Baran, Y.; Aktas, N.; Sahiner, N.; Water Res. 2009, 43, 4403.

14. Radhakrishnan, J.; Subramanian, A.; Krishnan, U. M.; Sethuraman, S.; Biomacromolecules 2017, 18, 1.

15. Pei, E.; Loh, G. H.; Prog. Addit. Manuf. 2018, 3, 95.

16. http://www.youtube.com/watch?v=0gMCZFHv9v8, accessed in January 2019.

17. Ahmed, E. M.; J. Adv. Res. 2015, 6, 105.

18. Jenkins, M.; Biomedical Polymers; CRC Press LLC: Boca Raton, USA, 2007.

19. Ullah, F.; Othman, M. B. H.; Javed, F.; Ahmad, Z.; Akil, H. M.; Mater. Sci. Eng., C 2015, 57, 414.

20. Milani, A. H.; Saunders, J. M.; Nguyen, N. T.; Ratcliffe, L. P.; Adlam, D. J.; Freemont, A. J.; Hoyland, J. A.; Armes, S. P.; Saunders, B. R.; Soft Matter 2017, 13, 1554.

21. Karg, M.; Wellert, S.; Prevost, S.; Schweins, R.; Dewhurst, C.; Liz-Marzán, L. M.; Hellweg, T.; Colloid Polym. Sci. 2011, 289 , 699.

22. Roland, C. M. In Encyclopedia of Polymeric Nanomaterials; Kobayashi, S.; Müllen, K., eds.; Springer-Verlag Berlin Heidelberg: Berlin, 2015, p. 1004-1011.

23. Champagne, P. O.; Westwick, H.; Bouthillier, A.; Sawan, M.; Nanomedicine 2018, 13, 1385.
24. Figuerola, A.; Di Corato, R.; Manna, L.; Pellegrino, T.; Pharmacol. Res. 2010, 62, 126.

25. Kumar, C. S.; Mohammad, F.; Adv. Drug Delivery Rev. 2011, 63, 789.

26. Laurent, S.; Dutz, S.; Häfeli, U. O.; Mahmoudi, M.; Adv. Colloid Interface Sci. 2011, 166, 8.

27. Jin, R.; Lin, B.; Li, D.; Ai, H.; Curr. Opin. Pharmacol. 2014, $18,18$.

28. Clarkson, R. B. In Contrast Agents I. Topics in Current Chemistry, vol. 221; Krause, W., ed.; Springer: Berlin, Heidelberg, 2002, p. 201-235.

29. Elias Jr., J.; Santos, A. C. D.; Koenigkam-Santos, M.; NogueiraBarbosa, M. H.; Muglia, V. F.; Radiol. Bras. 2008, 41, 263.

30. Shokrollahi, H.; Khorramdin, A.; Isapour, G.; J. Magn. Magn. Mater. 2014, 369, 176.

31. Mertens, M. E.; Hermann, A.; Bühren, A.; Olde-Damink, L.; Möckel, D.; Gremse, F.; Ehling, J.; Kiessling, F.; Lammers, T.; Adv. Funct. Mater. 2014, 24, 754.

32. Dadfar, S. M.; Roemhild, K.; Drude, N. I.; von Stillfried, S.; Knüchel, R.; Kiessling, F.; Lammers, T.; Adv. Drug Delivery Rev. 2019, 138, 302.

33. Reddy, L. H.; Arias, J. L.; Nicolas, J.; Couvreur, P.; Chem. Rev. 2012, 112, 5818.

34. Jaiswal, M. K.; De, M.; Chou, S. S.; Vasavada, S.; Bleher, R.; Prasad, P. V.; Bahadur, D.; Dravid, V. P.; ACS Appl. Mater. Interfaces 2014, 6, 6237.

35. Varanda, L. C.; Jafelicci Jr., M.; Beck Jr., W. In Biomedical Engineering, Trends in Materials Science; Lakovski, A., ed.; InTechOpen: London, 2011, p. 397-424.

36. Mahinroosta, M.; Farsangi, Z. J.; Allahverdi, A.; Shakoori, Z.; Mater. Today Chem. 2018, 8, 42.

37. Akhtar, M. F.; Hanif, M.; Ranjha, N. M.; Saudi Pharm. J. 2016, 24, 554.

38. Kolman, A.; Chovanec, M.; Osterman-Golkar, S.; Mutat. Res., Rev. Mutat. Res. 2002, 512, 173.

39. Gough, J. E.; Scotchford, C. A.; Downes, S.; J. Biomed. Mater. Res. 2002, 61, 121.

40. Greim, H.; The MAK-Collection for Occupation Health and Safety. Part I: MAK Value Documentations, vol. 25; Wiley-VCH: Weinheim, 2009.

41. Sasaki, Y.; Akiyoshi, K.; Chem. Rec. 2010, 10, 366.

42. Ye, X.; Li, X.; Shen, Y.; Chang, G.; Yang, J.; Gu, Z.; Polymer 2017, 108, 348.

43. Gulrez, S. K.; Al-Assaf, S.; Phillips, G. O. In Progress in Molecular and Environmental Bioengineering - From Analysis and Modeling to Technology Applications; Carpi, A., ed.; InTechOpen: London, 2011, p. 117-150.

44. Oh, J. K.; Soft Matter 2011, 7, 5096.

45. Qi, X.; Hu, X.; Wei, W.; Yu, H.; Li, J.; Zhang, J.; Dong, W.; Carbohydr. Polym. 2015, 118, 60. 
46. Masruchin, N.; Park, B. D.; Causin, V.; J. Ind. Eng. Chem. 2015, $29,265$.

47. Miyazaki, T.; Takeda, Y.; Akane, S.; Itou, T.; Hoshiko, A.; En, K.; Polymer 2010, 51, 5539.

48. Bueno, V. B.; Bentini, R.; Catalani, L. H.; Petri, D. F. S.; Carbohydr. Polym. 2013, 92, 1091.

49. Lai, J. Y.; J. Mater. Sci.: Mater. Med. 2010, 21, 1899.

50. Ibrahim, S.; Kang, Q. K.; Ramamurthi, A.; J. Biomed. Mater. Res., Part A 2010, 94, 355.

51. Zhang, Y.; Zhu, P. C.; Edgren, D.; J. Polym. Res. 2010, 17, 725.

52. Hennink, W. E.; van Nostrum, C. F.; Adv. Drug Delivery Rev. 2012, 64, 223.

53. Sokker, H. H.; El-Sawy, N. M.; Hassan, M. A.; El-Anadouli, B. E.; J. Hazard. Mater. 2011, 190, 359.

54. Abdel-Halim, E. S.; Al-Deyab, S. S.; Carbohydr. Polym. 2011, $86,1306$.

55. Teixeira, L. S. M.; Feijen, J.; van Blitterswijk, C. A.; Dijkstra, P. J.; Karperien, M.; Biomaterials 2012, 33, 1281.

56. Siddiqui, M. N.; Redhwi, H. H.; Tsagkalias, I.; Softas, C.; Ioannidou, M. D.; Achilias, D. S.; Thermochim. Acta 2016, $643,53$.

57. Varaprasad, K.; Raghavendra, G. M.; Jayaramudu, T.; Yallapu, M. M.; Sadiku, R.; Mater. Sci. Eng., C 2017, 79, 958.

58. Lu, A. H.; Salabas, E. E.; Schüth, F.; Angew. Chem., Int. Ed. 2007, 46, 1222.

59. Li, Y.; Huang, G.; Zhang, X.; Li, B.; Chen, Y.; Lu, T.; Lu, T. J.; Xu, F.; Adv. Funct. Mater. 2013, 23, 660.

60. Bueno, V. B.; Silva, A. M.; Barbosa, L. R. S.; Catalani, L. H.; Teixeira-Neto, É.; Cornejo, D. R.; Petri, D. F. S.; Chem. Commun. 2013, 49, 9911.

61. Kim, J. I.; Chun, C.; Kim, B.; Hong, J. M.; Cho, J. K.; Lee, S. H.; Song, S. C.; Biomaterials 2012, 33, 218.

62. Muzzalupo, R.; Tavano, L.; Rossi, C. O.; Picci, N.; Ranieri, G. A.; Colloids Surf., B 2015, 134, 273.

63. Zhang, J.; Huang, Q.; Du, J.; Polym. Int. 2016, 65, 1365.

64. Castro, P. S.; Bertotti, M.; Naves, A. F.; Catalani, L. H.; Cornejo, D. R.; Bloisi, G. D.; Petri, D. F.; Colloids Surf., B 2017, 156, 388.

65. https://www.youtube.com/watch?v=obhU4g4_rRY, accessed in January 2019.

66. Glaser, T.; Bueno, V. B.; Cornejo, D. R.; Petri, D. F.; Ulrich, H.; Biomed. Mater. 2015, 10, 045002.

67. Nguyen-Thai, N. U.; Vietnam J. Sci. Technol. 2018, 56, 167.

68. Tang, J.; Tong, Z.; Xia, Y.; Liu, M.; Lv, Z.; Gao, Y.; Lu, T.; Xie, S.; Pei, Y.; Fang, D.; Wang, T. J.; J. Mater. Chem. B 2018, 6, 2713.

69. Dai, Q. Q.; Ren, J. L.; Peng, F.; Chen, X. F.; Gao, C. D.; Sun, R. C.; Materials 2016, 9, 690.

70. Helminger, M.; Wu, B.; Kollmann, T.; Benke, D.; Schwahn, D.; Pipich, V.; Faivre, D.; Zahn, D.; Cölfen, H.; Adv. Funct. Mater. 2014, 24, 3187.
71. Horst, M. F.; Ninago, M. D.; Lassalle, V.; Int. J. Polym. Mater. 2018, 67, 647.

72. Ilg, P.; Soft Matter 2013, 9, 3465.

73. Kango, S.; Kalia, S.; Celli, A.; Njuguna, J.; Habibi, Y.; Kumar, R.; Prog. Polym. Sci. 2013, 38, 1232.

74. Basuki, J. S.; Esser, L.; Zetterlund, P. B.; Whittaker, M. R.; Boyer, C.; Davis, T. P.; Macromolecules 2013, 46, 6038.

75. Barbucci, R.; Pasqui, D.; Giani, G.; De Cagna, M.; Fini, M.; Giardino, R.; Atrei, A.; Soft Matter 2011, 7, 5558.

76. Giani, G.; Fedi, S.; Barbucci, R.; Polymers 2012, 4, 1157.

77. Gibson, L. J.; Ashby, M. F.; Cellular Solids: Structure and Properties, $2^{\text {nd }}$ ed.; Cambridge University Press: Cambridge, 1999.

78. Paulino, A. T.; Pereira, A. G.; Fajardo, A. R.; Erickson, K.; Kipper, M. J.; Muniz, E. C.; Belfiore, L. A.; Tambourgi, E. B.; Carbohydr. Polym. 2012, 90, 1216.

79. Lia, Y. S.; Church, J. S.; Woodhead, A. L.; J. Magn. Magn. Mater. 2012, 324, 1543.

80. Chen, M. H.; Chung, J. J.; Mealy, J. E.; Zaman, S.; Li, E. C.; Arisi, M. F.; Atluri, P.; Burdick, J. A.; Macromol. Biosci. 2018, 19, DOI: 10.1002/mabi.201800248.

81. Mathew, A. P.; Uthaman, S.; Cho, K. H.; Cho, C. S.; Park, I. K.; Int. J. Biol. Macromol. 2018, 110, 17.

82. Joas, S.; Tovar, G.; Celik, O.; Bonten, C.; Southan, A.; Gels 2018, 4, 69.

83. Gila-Vilchez, C.; Bonhome-Espinosa, A. B.; Kuzhir, P.; Zubarev, A.; Duran, J. D.; Lopez-Lopez, M. T.; J. Rheol. 2018, 62, 1083.

84. Wang, Y.; Song, C.; Yu, X.; Liu, L.; Han, Y.; Chen, J.; Fu, J.; Compos. Sci. Technol. 2017, 151, 139.

85. Qu, J.; Zhao, X.; Ma, P. X.; Guo, B.; Acta Biomater. 2018, 72, 55.

86. Zhao, W.; Odelius, K.; Edlund, U.; Zhao, C.; Albertsson, A. C.; Biomacromolecules 2015, 16, 2522.

87. Koetting, M. C.; Peters, J. T.; Steichen, S. D.; Peppas, N. A.; Mater. Sci. Eng., $R$ 2015, 93, 1.

88. Xu, L.; Qiu, L.; Sheng, Y.; Sun, Y.; Deng, L.; Li, X.; Bradley, M.; Zhang, R.; J. Mater. Chem. B 2018, 6, 510.

89. Dragan, E. S.; Cocarta, A. I.; ACS Appl. Mater. Interfaces 2016, $8,12018$.

90. Langer, R.; Chem. Eng. Commun. 1980, 6, 1.

91. Siegel, R. A.; Langer, R.; Pharm. Res. 1984, 1, 2.

92. Yegappan, R.; Selvaprithiviraj, V.; Amirthalingam, S.; Jayakumar, R.; Carbohydr. Polym. 2018, 198, 385.

93. Ta, H. T.; Dass, C. R.; Larson, I.; Choong, P. F.; Dunstan, D. E.; Biomaterials 2009, 30, 3605.

94. Nazli, C.; Demirer, G. S.; Yar, Y.; Acar, H. Y.; Kizilel, S.; Colloids Surf., B 2014, 122, 674.

95. Merino, S.; Martin, C.; Kostarelos, K.; Prato, M.; Vazquez, E.; ACS Nano 2015, 9, 4686.

96. Wang, Y.; Kohane, D. S.; Nat. Rev. Mater. 2017, 2, 17020.

97. Wang, Y.; Li, B.; Xu, F.; Han, Z.; Wei, D.; Jia, D.; Zhou, Y.; Biomacromolecules 2018, 19, 3351. 
98. Kondaveeti, S.; Cornejo, D. R.; Petri, D. F. S.; Colloids Surf., B 2016, 138, 94.

99. Kondaveeti, S.; Semeano, A. T. S.; Cornejo, D. R.; Ulrich, H.; Petri, D. F. S.; Colloids Surf., B 2018, 167, 415.

100. Mahdavinia, G. R.; Etemadi, H.; Soleymani, F.; Carbohydr. Polym. 2015, 128, 112.

101. Mahdavinia, G. R.; Afzali, A.; Etemadi, H.; Hoseinzadeh, H.; Nanomed. Res. J. 2017, 2, 111.

102. Bajpai, A. K.; Gupta, R.; Mater. Sci. Mater. Med. 2011, 22, 357.

103. Bi, H.; Ma, S.; Li, Q.; Han, X.; J. Mater. Chem. B 2016, 4 , 3269.

104. Finotelli, P. V.; da Silva, D.; Sola-Penna, M.; Rossi, A. M.; Farina, M.; Andrade, L. R.; Takeuchi, A. Y.; Rocha-Leão, M. H.; Colloids Surf., B 2010, 81, 206.

105. Likhitkar, S.; Bajpai, A. K.; Carbohydr. Polym. 2012, 87, 300. 106. Bueno, P. V.; Hilamatu, K. C.; Carmona-Ribeiro, A. M.; Petri, D. F.; Int. J. Biol. Macromol. 2018, 115, 792.

107. Vashist, A.; Kaushik, A.; Vashist, A.; Bala, J.; Nikkhah-Moshaie, R.; Sagar, V.; Nair, M.; Drug Discovery Today 2018, 23, 1436.

108. Vashist, A.; Vashist, A.; Gupta, Y. K.; Ahmad, S.; J. Mater. Chem. B 2014, 2, 147.

109. Anirudhan, T. S.; Parvathy, J.; Nair, A. S.; Carbohydr. Polym. 2016, 136, 1118.

110. Zhang, J.; Zhao, L.; Zhang, J.; Zhang, Z.; Le, Y.; Wen, N.; Wang, J.; J. Appl. Polym. Sci. 2016, 133, DOI 10.1002/APP.43111.

111. Ribeiro, L. N.; Alcântara, A. C.; Darder, M.; Aranda, P.; Herrmann Jr., P. S.; Araújo-Moreira, F. M.; Hernández, M. G.; Ruiz-Hitzky, E.; Int. J. Pharm. 2014, 477, 553.

112. Liu, T. Y.; Hu, S. H.; Liu, T. Y.; Liu, D. M.; Chen, S. Y.; Langmuir 2006, 22, 5974 .

113. Satarkar, N. S.; Hilt, J. Z.; J. Controlled Release 2008, 130, 246.

114. Dhandayuthapani, B.; Yoshida, Y.; Maekawa, T.; Kumar, D. S.; Int. J. Polym. Sci. 2011, article ID 290602.

115. Lin, S. T.; Kimble, L.; Bhattacharyya, D.; Biomaterials for Implants and Scaffolds; Li, Q.; Mai, Y.-W., eds.; Springer: Berlin, 2017, p. 195-235.

116. Diekjürgen, D.; Grainger, D. W.; Biomaterials 2017, 141, 96.

117. Campos, F.; Bonhome-Espinosa, A. B.; Vizcaino, G.; Rodriguez, I. A.; Duran-Herrera, D.; López-López, M. T.; SanchezMontesinos, I.; Alaminos, M.; Sánchez-Quevedo, M.; Carriel, V.; Biomed. Mater. 2018, 13, 025021.

118. Ghasemi-Mobarakeh, L.; World J. Stem Cells 2015, 7, 728.

119. Gil, S.; Mano, J. F.; Biomater. Sci. 2014, 2, 812.

120. Semeano, A. T.; Glaser, T.; Ulrich, H.; Petri, D. F. S. In Working with Stem Cells; Ulrich, H.; Negraes, P. D., eds.; Springer International Publishing Switzerland, 2016, p. 347-365, DOI: 10.1007/978-3-319-30582-0.

121. Patil, R. M.; Thorat, N. D.; Shete, P. B.; Bedge, P. A.; Gavde, S.; Joshi, M. G.; Tofail, S. A. M.; Bohara, R. A.; Biochem. Biophys. Rep. 2018, 13, 63.

122. Revia, R. A.; Zhang, M.; Mater. Today 2016, 19, 157.
123. Mahmoudi, M.; Laurent, S.; Shokrgozar, M. A.; Hosseinkhani, M.; ACS Nano 2011, 5, 7263.

124. Zhang, N.; Lock, J.; Sallee, A.; Liu, H.; ACS Appl. Mater. Interfaces 2015, 7, 20987.

125. Bock, N.; Riminucci, A.; Dionigi, C.; Russo, A.; Tampieri, A.; Landi, E.; Goranov, V. A.; Marcacci, M.; Dediu, V.; Acta Biomater. 2010, 6, 786.

126. Meng, J.; Xiao, B.; Zhang, Y.; Liu, J.; Xue, H.; Lei, J.; Kong, H.; Huang, Y.; Jin, Z.; Gu, N.; Xu, H.; Sci. Rep. 2013, 3, 2655.

127. Yun, H.-M.; Ahn, S.-J.; Park, K.-R.; Kim, M.-J.; Kim, J.-J.; Jin, G.-Z.; Kim, H.-W.; Kim, E.-C.; Biomaterials 2016, 85, 88.

128. Tampieri, A.; Iafisco, M.; Sandri, M.; Panseri, S.; Cunha, C.; Sprio, S.; Savini, S.; Uhlarz, M.; Hermannsdofer, T.; ACS Appl. Mater. Interfaces 2014, 6, 15697.

129. Silva, E. D.; Babo, P. S.; Costa-Almeida, R.; Domingues, R. M. A.; Mendes, B. B.; Paz, E.; Freitas, P.; Rodrigues, M. T.; Granja, P. L.; Gomes, M. E.; Nanomedicine 2018, 14, 2375.

130. Sapir, Y.; Cohen, S.; Friedman, G.; Polyak, B.; Biomaterials 2012, 33, 4100.

131. Hogan, M.; Chen, Y.-T.; Kolhatkar, A. G.; Candelari, C. J.; Madala, S.; Lee, T. R.; Birla, R.; ACS Biomater. Sci. Eng. 2016, 2,1619 .

132. Bueno, V. B.; Takahashi, S. H.; Catalani, L. H.; de Torresi, S. I. C.; Petri, D. F. S.; Mater. Sci. Eng., C 2015, 52, 121.

133. Gil, S.; Silva, J. M.; Mano, J. F.; ACS Biomater. Sci. Eng. 2015, $1,1016$.

134. Tay, A.; Kunze, A.; Murray, C.; Di Carlo, D.; ACS Nano 2016, 10, 2331.

135. Rao, K. M.; Kumar, A.; Han, S. S.; J. Mater. Sci. Technol. 2018, 34, 1371.

136. Kim, J. J.; Singh, R. K.; Seo, S. J.; Kim, T. H.; Kim, J. H.; Lee, E. J.; Kim, H. W.; RSC Adv. 2014, 4, 17325.

137. Xu, H. Y.; Gu, N.; Front. Mater. Sci. 2014, 8, 20.

138. Davila, A. F.; Fleissner, G.; Winklhofer, M.; Petersen, N.; Phys. Chem. Earth, Parts A/B/C 2003, 28, 647.

139. Lohmann, K. J.; Nature 2010, 464, 1140.

140. Gao, L.; Zhuang, J.; Nie, L.; Zhang, J.; Zhang, Y.; Gu, N.; Wang, T.; Feng, J.; Yang, D.; Perrett, S.; Yan, X.; Nat. Nanotechnol. 2007, 2, 577.

141. Huang, D. M.; Hsiao, J. K.; Chen, Y. C.; Chien, L. Y.; Yao, M.; Chen, Y. K.; Ko, B. S.; Hsu, S. C.; Tai, L. A.; Cheng, H. Y.; Wang, S. W.; Yang, C. S.; Chen, Y. C.; Biomaterials 2009, 30, 3645 .

142. Jain, T. K.; Reddy, M. K.; Morales, M. A.; Leslie-Pelecky, D. L.; Labhasetwar, V.; Mol. Pharmaceutics 2008, 5, 316.

143. Edmondson, R.; Broglie, J. J.; Adcock, A. F.; Yang, L.; Assay Drug Dev. Technol. 2014, 12, 207.

144. Breslin, S.; O’Driscoll, L.; Drug Discovery Today 2013, 18, 240.

145. van Duinen, V.; Trietsch, S. J.; Joore, J.; Vulto, P.; Hankemeier, T.; Curr. Opin. Biotechnol. 2015, 35, 118. 
146. Souza, G. R.; Molina, J. R.; Raphael, R. M.; Ozawa, M. G.; Stark, D. J.; Levin, C. S.; Bronk, L. F.; Ananta, J. S.; Mandelin, J.; Georgescu, M.-M.; Bankson, J. A.; Gelovani, J. G.; Killian, T. C.; Arap, W.; Pasqualini, R.; Nat. Nanotechnol. 2010, 5, 291.

147. Strebhardt, K.; Ullrich, A.; Nat. Rev. Cancer 2008, 8, 473.

148. Freeman, M. W.; Arrott, A.; Watson, J. H. L.; J. Appl. Phys. 1960, 31, S404.

149. Zimmermann, U.; Pilwat, G.; J. Biosci. 1976, 31, 732.

150. Widder, K. J.; Senyel, A. E.; Scarpelli, G. D.; Proc. Soc. Exp. Biol. Med. 1978, 158, 141.

151. Rao, L.; Bu, L. L.; Meng, Q. F.; Cai, B.; Deng, W. W.; Li, A.; Li, K.; Guo, S. S.; Zhang, W. F.; Liu, W.; Sun, Z. J.; Adv. Funct. Mater. 2017, 27, 1604774.

152. Borghi, E.; Levy, L.; Pottier, A.; U.S. pat. 10,098,952 2018.

153. Nosrati, H.; Sefidi, N.; Sharafi, A.; Danafar, H.; Manjili, H. K.; Bioorg. Chem. 2018, 76, 501.

154. Zhang, D.; Sun, P.; Li, P.; Xue, A.; Zhang, X.; Zhang, H.; Jin, X.; Biomaterials 2013, 34, 10258.

155. Richterstetter, M.; Wullich, B.; Amann, K.; Haeberle, L.; Engehausen, D. G.; Goebell, P. J.; Krause, F. S.; BJU Int. 2012, 110, E76.

156. Ta, H. T.; Dass, C. R.; Larson, I.; Choong, P. F.; Dunstan, D. E.; Biomaterials 2009, 30, 3605.

157. Xie, W.; Gao, Q.; Guo, Z.; Wang, D.; Gao, F.; Wang, X.; Wei, Y.; Zhao, L.; ACS Appl. Mater. Interfaces 2017, 9, 3660.

158. Khiabani, S. S.; Farshbaf, M.; Akbarzadeh, A.; Davaran, S.; Artif. Cells, Nanomed., Biotechnol. 2017, 45, 6.

159. Kowal, C. D.; Bertino, J. R.; Cancer Res. 1979, 39, 2285.

160. Hervault, A.; Thanh, N. T. K.; Nanoscale 2014, 6, 11553.

161. Meenach, S. A.; Hilt, J. Z.; Anderson, K. W.; Acta Biomater. 2010, 6, 1039

162. Zhu, X.; Zhang, H.; Huang, H.; Zhang, Y.; Hou, L.; Zhang, Z.; Nanotechnology 2015, 26, 365103.

163. Lin, T. C.; Lin, F. H.; Lin, J. C.; Acta Biomater. 2012, 8, 2704.

164. Song, X.; Luo, X.; Zhang, Q.; Zhu, A.; Ji, L.; Yan, C.; J. Magn. Magn. Mater. 2015, 388, 116.

165. Liu, G.; Hong, R. Y.; Guo, L.; Li, Y. G.; Li, H. Z.; Appl. Surf. Sci. 2011, 257, 6711.

166. Kim, H.; Jo, A.; Baek, S.; Lim, D.; Park, S. Y.; Cho, S. K.; Chung, J. W.; Yoon, J.; Sci. Rep. 2017, 7, 41090.

167. Zhang, Z. Q.; Song, S. C.; Biomaterials 2016, 106, 13.

168. Brulé, S.; Levy, M.; Wilhelm, C.; Letourneur, D.; Gazeau, F.; Ménager, C.; Le Visage, C.; Adv. Mater. 2011, 23, 787.

169. Jaiswal, M. K.; Gogoi, M.; Sarma, H. D.; Banerjee, R.; Bahadur, D.; Biomater. Sci. 2014, 2, 370.

170. Wu, H.; Song, L.; Chen, L.; Zhang, W.; Chen, Y.; Zang, F.; Chen, H.; Ma, M.; Gu, N.; Zhang, Y.; Acta Biomater. 2018, 74, 302.

171. Xue, W.; Liu, X. L.; Ma, H.; Xie, W.; Huang, S.; Wen, H.; Jing, G.; Zhao, L.; Liang, X.-J.; Fan, H. M.; J. Mater. Chem. B 2018, 6, 2289.
172. Zhou, X.; Wang, L.; Xu, Y.; Du, W.; Cai, X.; Wang, F.; Ling, Y.; Chen, H.; Wang, Z.; Hu, B.; Zheng, Y.; RSC Adv. 2018, 8, 9812.

173. https://www.eea.europa.eu/publications/92-827-5122-8/ page011.html, accessed in January 2019.

174. Sikder, T.; Rahman, M.; Hosokawa, T.; Kurasaki, M.; Saito, T.; Chem. Eng. J. 2019, 355, 920.

175. de Souza, Í. F. T.; Petri, D. F. S.; J. Mol. Liq. 2018, 266, 640.

176. Zhang, J.; Guo, D. S.; Wang, L. H.; Wang, Z.; Liu, Y.; Soft Matter 2011, 7, 1756.

177. https://www.epa.gov/ccl/types-drinking-water-contaminants, accessed in January 2019.

178. de Carvalho, G. G. A.; Kondaveeti, S.; Petri, D. F. S.; Fioroto, A. M.; Albuquerque, L. G.; Oliveira, P. V.; Talanta 2016, 161, 707.

179. Khan, M.; Lo, I. M.; Water Res. 2016, 106, 259.

180. Tang, S. C. N.; Yan, D. Y. S.; Lo, I. M. C.; Ind. Eng. Chem. Res. 2014, 53, 15718.

181. Zhou, Y.; Fu, S.; Zhang, L.; Zhan, H.; Levit, M. V.; Carbohydr. Polym. 2014, 101, 75.

182. Zheng, X.; Wu, D.; Su, T.; Bao, S.; Liao, C.; Wang, Q.; ACS Appl. Mater. Interfaces 2014, 6, 19840.

183. Huang, B.; Lu, M.; Wang, D.; Song, Y.; Zhou, L.; Carbohydr. Polym. 2018, 181, 785.

184. Yang, H. M.; Hwang, J. R.; Lee, D. Y.; Kim, K. B.; Park, C. W.; Kim, H. R.; Lee, K. W.; Sci. Rep. 2018, 8, 11476.

185. Zhu, H.; Fu, Y.; Jiang, R.; Yao, J.; Xiao, L.; Zeng, G.; Ind. Eng. Chem. Res. 2014, 53, 4059.

186. Areal, M. P.; Arciniegas, M. L.; Horst, F.; Lassalle, V.; Sánchez, F. H.; Alvarez, V. A.; Gonzalez, J. S.; J. Polym. Environ. 2018, 26, 3129 .

187. Abasiyan, S. M. A.; Mahdavinia, G. R.; Environ. Sci. Pollut. Res. 2018, 25, 14977.

188. Wu, D.; Zhao, J.; Zhang, L.; Wu, Q.; Yang, Y.; Hydrometallurgy 2010, 101, 76 .

189. Paulino, A. T.; Belfiore, L. A.; Kubota, L. T.; Muniz, E. C.; Almeida, V. C.; Tambourgi, E. B.; Desalination 2011, 275, 187.

190. Li, K.; Wang, Y.; Huang, M.; Yan, H.; Yang, H.; Xiao, S.; Li, A.; J. Colloid Interface Sci. 2015, 455, 261.

191. Pour, Z. S.; Ghaemy, M.; RSC Adv. 2015, 5, 64106.

192. Aksoy, T.; Erdemir, S.; Yildiz, H. B.; Yilmaz, M.; Water, Air, Soil Pollut. 2012, 223, 4129.

193. Lakouraj, M. M.; Mojerlou, F.; Zare, E. N.; Carbohydr. Polym. 2014, 106, 34.

194. Sun, X.-F.; Liu, B.; Jing, Z.; Wang, H.; Carbohydr. Polym. 2015, $118,16$.

195. Badruddoza, A. Z. M.; Hazel, G. S. S.; Hidajat, K.; Uddin, M. S.; Colloids Surf., A 2010, 367, 85.

196. Novaes, S. D.; Oliveira, P. V.; Petri, D. F. S.; ChemPlusChem 2017, 82, 904. 
197. Lei, Y.; Chen, F.; Luo, Y.; Zhang, L.; J. Mater. Sci. 2014 , 49, 4236.

198. Kadam, A. A.; Lee, D. S.; Bioresour. Technol. 2015, 193, 563.

199. Zhang, W.; Zhu, Z.; Zhang, H.; Qiu, Y.; Int. J. Environ. Res. Public Health 2017, 14, 991.

200. Ur Rehman, S.; Siddiq, M.; Al-Lohedan, H.; Aktas, N.; Sahiner, M.; Demirci, S.; Sahiner, N.; J. Environ. Manage. 2016, 166 , 217.

201. Ozay, O.; Ekici, S.; Baran, Y.; Kubilay, S.; Aktas, N.; Sahiner, N.; Desalination 2010, 260, 57.

202. Du, R.; Zhao, Q.; Zheng, Z.; Hu, W.; Zhang, J.; Adv. Energy Mater. 2016, 6, 1600473.
203. Yan, Q.; Dong, H.; Su, J.; Han, J.; Song, B.; Wei, Q.; Shi, Y.; Engineering 2018, 4, 729.

204. Khoo, Z. X.; Teoh, J. E. M.; Liu, Y.; Chua, C. K.; Yang, S.; An, J.; Leorg, K. F.; Yeong, W. Y.; Virtual Phys. Prototyping 2015, $10,103$.

205. Zhu, P.; Yang, W.; Wang, R.; Gao, S.; Li, B.; Li, Q.; ACS Appl. Mater. Interfaces 2018, 10, 36435.

206. https://www.youtube.com/watch?v=MUt1YKtn6kM, accessed in January 2019.

Submitted: February 3, 2019

Published online: April 26, 2019 